\title{
Behavioral differentiation and hybridization of the European and Asian forms of Harting' vole Microtus hartingi (Rodentia, Arvicolinae)
}

\author{
Tanya A. Zorenko*, Nasko Atanasov, Fedor N. Golenishchev
}

\begin{abstract}
The final isolation of Europe from Asia took place comparatively not long ago — in the early Holocene - late Pleistocene which led to the division of Microtus hartingi area into two isolated parts (Asian-Central and West Anatolia and European-southern Balkans). The Northern Mediterranean was influenced by considerable climatic and habitat fluctuations that caused fragmentation of a potential area of Microtus hartingi and promoted microevolutionary processes. The purpose of the work was evaluation of the range disjunction influence on diversification of the species. We analyzed (1) copulatory behavior, (2) exploratory activity and ability to overcome the stress, (3) growth and development of pups, and also (4) hybridization success in the two nominal forms of $M$. hartingi $-M . h$. lydius and $M$. $h$. strandzensis. Considerable changes in behavior of individuals of two subspecies were obtained. As a result of the hybridization of the two forms, viable and prolific posterity of F1 was received, but the subsequent cross breeding including backcrossing sterility of males and high mortality of posterity began to be established. The testes and the epididymis of the hybrids were with smaller weight in comparison with parents' subspecies, especially $M$. h. lydius, reduced quantity of spermatozoa and small percent mobile of them which confirmed the lower level of spermatogenesis. We assume that evolution of the phenotypic characteristics of the voles was supported by gene drift and probably by the selection, induced by the stress more strongly, than changes in the genotypic characteristics, e.g. distinctions on cytochrome $b$ and the karyotype are not significant. This can be explained as an influence of specific ecological conditions and fragmentation of the habitats in the Northern Mediterranean Region. Until recently M. h. lydius and $M$. h. strandzensis were considered as subspecies. However, they reached considerable degree of a divergence and the question of their specific status has to be considered additionally.
\end{abstract}

KEY WORDS: social voles, Microtus hartingi, hybridization, male reproductive system, spermatozoa, sterility, ontogenesis, exploratory behavior, copulatory behavior, reproductive isolation, systematic.

Tanya A. Zorenko [zorenkot@lanet.lv], University of Latvia, Elgavas 1, Riga LV-1586, Elgavas 1, Latvia; Nasko I. Atanasov [naskoat@gmail.com], Institute of Biodiversity and Ecosystem Research, Bulgarian Academy of Sciences, Tsar Osvoboditel blvd. 1, 1000 Sofia, Bulgaria; Fedor N.Golenishchev [f gol@mail.ru], Zoological Institute, Russian Academy of Science, Universitetkaya emb. 1, Saint Petersburg 199034, Russia.

\section{Поведение и гибридизация европейкой и азиатской форм полевки Хартинга Microtus hartingi (Rodentia, Arvicolinae)}

\author{
Т.А. Зоренко*, Н.И. Атанасов, Ф.Н. Голенищев
}

РЕЗЮМЕ. Окончательная изоляция Европы от Малой Азии произошла относительно недавно, а именно в начале голоцена - конце позднего плейстоцена, что привело к разделению ареала Microtus hartingi на два изолированных участка (азиатский - центральная и западная Анатолия и европейский - южные Балканы). Северное Средиземноморье испытывало на себе значительные климатические и биотопические флуктуации, что вызывало фрагментацию потенциального ареала Microtus hartingi и способствовало микроэволюционным процессам. Целью работы было выявить влияние дизъюнкции ареала на диверсификацию вида. Мы проанализировали у двух подвидов M. hartingi, европейского - M. h. strandzensis и малоазиатского - M. h. lydius, (1) половое поведение, (2) исследовательскую активность и способность преодолевать стресс, (3) рост и развитие детенышей, а также (4) их репродуктивную совместимость при гибридизации M. h. strandzensis/M. h. lydius. Были показаны значительные изменения поведения особей двух подвидов. Хотя при гибридизации двух форм, получено жизнеспособное и плодовитое потомство F1, при последующем скрещивании, в том числе и возвратном, стала проявляться стерильность самцов и высокая смертность потомства. Гибриды имели меньшие по массе семенники и их придатки по сравнению с родительскими 
подвидами, особенно M. h. lydius, малое количество сперматозоидов, с небольшим количеством подвижных сперматозоидов, что свидетельствует о пониженном сперматогенезе. Мы предполагаем, что эволюция фенотипических характеристик у полевок поддерживалась генетическим дрейфом и, возможно, отбором под действием стерессирующего фактора, вызванного экологической спецификой и фрагментацией биотопов северного средиземноморского региона, сильнее, чем изменения генотипических показателей (различия по суt b и кариотипу незначительны). По настоящее время $M$. h. lydius и M. h. strandzensis рассматриваются как подвиды. Однако они достигли значительной степени дивергенции, и вопрос о видовом статусе должен быть рассмотрен дополнительно.

КЛЮЧЕВЫЕ СЛОВА: общественные полевки, Microtus hartingi, гибридизация, половая система самцов, сперматогенез, стерильность, онтогенез, исследовательское поведение, половое поведение, репродуктивная изоляция, систематика.

\section{Introduction}

The Balkan Peninsula, being at the South-Eastern margin of Europe and natural border for European populations also is a biogeographical bridge between Asia and Europe and has provided many examples of genetically differentiated lineages within several widely distributed species (Perissoratis \& Conispoliatis, 2003). One typical example is Gunther's vole - M. (Sumeriomys) guentheri Danford et Alston, 1880. Until recently, it was thought that this species is represented by several well differentiated subspecies: M. g. guentheri (the South-Eastern Turkey), M. g. philistinus Thomas, 1917 (Israel); M. g. mustersi Hinton, 1926 - the only species of the subfamily Arvicolinae, which is distributed in Africa (Libya); M. g. hartingi BarretHamilton, 1903 (Greece); M. g.lydius Blackler, 1916 (Western part of Turkey); M. g. martinoi Petrov, 1939 (Macedonia); M. g. strandzensis Markov, 1960 (Bulgaria); M. g. ankaraensis Yigit et Colak, 2002 (Central Turkey); M. g. shevketi Neuhauser, 1936 (Southern and Central Turkey) (Musser \& Carleton, 2005). The position of $M . g$. mustersi is still controversial, although according to the Thanou et al. (2011) the results of cyt $b$ analyses suggest that it is a separate sisterly relict species of M. guentheri from Israel, Syria and SouthEastern Turkey. The question of the taxonomic status of voles from the Balkans and Anatolia has been discussed for a long time. On the basis of morphometric data on the structure of the skull, it was assumed that the M. guentheri from South-Eastern Turkey differ from those of Central and Western Anatolia and respectively represented by two separate species - M. guentheri and M. lydius, which is newly described as a subspecies M. lydius ankaraensis (Central Anatolia) (Yi it \& Çolak, 2002). According to the cyt $b$ analysis was found that $M$. guentheri consists of two allopatric species: $M$. guentheri (Syria, Israel) and M. hartingi (Anatolia and the Balkans). According to the rule of the priority it should be called M. hartingi Barret-Hamilton, 1903 (Kryštufek et al., 2009). This point of view has been confirmed as the molecular-genetic data as well as from the experimental hybridization between $M$. $h$. lydius from Central Anatolia and M. guentheri from «terra typica» region of Türko lu, Kahramanmara , Turkey
(Golenishchev \& Abramson, 2011; Golenishchev \& Malikov, 2011). Currently, two subspecies of M. hartingi (M. h. lydius, $M . h$. ankaraensis) are widely distributed in the Central and Western Turkey (Kryštufek \& Vohrálik, 2005). In Strandhza Mountain (Bulgaria) the subspecies $M$. h. strandzensis is presented (Markov, 1960), which appear to be similar to the voles living on the Turkish part of the Strandzha Mountain. In Bulgaria $M$. hartingi forms a small isolate in the Rhodope Mountains too. Communication between the populations of Strandhza and Rhodopes Mountain is not established. Probably the voles from Rhodopes locality are closely with these from neighboring Greece, where the $M . h$. hartingi subspecies range is narrow, but there is evidence that the voles are settled and expanded its territory (Thanou et al., 2012). Therefore, new data are needed to explain the mechanisms that have led to the current interspecies' structure of the species. Only for one representative of the group "guentheri" - M. $h$. strandzensis different forms of behavior such as exploratory (Zorenko et al., 1989), play (Zorenko \& Andersone, 1996), copulative (Zorenko, 2000) and social (Zorenko, 2013) are sufficiently studied. Behavioral studies on the other subspecies $M$. hartingi, including $M$. h. lydius are not conducted. Experimental hybridization of M. h. strandzensis and M. socialis (Zorenko et al., 1997) showed a sterility of inter-species hybrid males and females. Hybridization of $M . h$. lydius and $M . h$. strandzensis is not studied. Few data on the behavior of hybrids in the literature can be found, while the behavior and reproduction of hybrids may indicate possible reproductive pre- or post zygotic isolation between compared taxa (Erman \& Parson, 1984; Zorenko, 2013).

Thus, the purpose of our work is to study behavior characteristics (exploratory and pairing behavior), hybridization and ontogenetic characteristics of the two subspecies of Harting's vole ( $M$. hartingi). The analysis of the results will clarify some of the issues related to the degree of divergence of different forms in microevolutionary process.

\section{Material and methods}

The founders of the laboratory colony of Harting's voles $M . h$. lydius were caught in Turkey (vicinity of 
$\mathrm{K} \mathrm{r}$ ehir). Males of $M$. h. strandzensis from Strandzha Mountains (Bulgaria, Gramatikovo's vicinities) were used in the experimental hybridization. The investigations were carried out in 2013-2015. Data from Asian and European populations for the copulative (Zorenko, 2000) and exploratory behavior of $M . h$. strandzensis (Zorenko, 2013) as well as for the growth and rates of formation of exterior signs (Golenishchev et al., 1991; Zorenko, 2013) were used. The keeping of animals satisfied the requirements of Federation of European Laboratory Animal Science Associations (FELASA, certificate C-category). Animals were sacrificed by cervical dislocation, which is regarded as a humane method. The animals were kept in standard laboratory cages. Wood sawdust and hay were used as litter material. Vegetables and grains mixture were the basic nutrition of the voles. In spring and summer the animals were given grass in addition. Temperature in the vivarium was $20 \pm 2^{\circ} \mathrm{C}$ and light/dark cycle of $12 \mathrm{~L} / 12 \mathrm{D}$ was maintained.

Hybridization. Pairs consist from sexually mature males $M . h$. strandzensis and females $M$. h. lydius. For an estimation of reproduction intensity at hybridization the following parameters were used: number of the females who started reproduction, an average time interval till the birth of the first litter and also the number of the pups in every litter as well as parent's and pups mortality. In case the offspring was not received, tests were finished after 2.5-3.0 months from the moment of their coupling and putting together. 92 experiments of hybridization were made. Reproductive activity of the hybrids by the relative concentration (from 0 to $100 \%$ ) and the mobility of spermatozoa were estimated (Kurilo, 2001). The content of an epididymis is squeezed out on microscope glass to which was added $20 \mu 1$ physiological solution. The received preparation at a temperature of $20^{\circ} \mathrm{C}$ was observed under a microscope "Ergoval" at increase $10 \times 16$. A part of diluted preparation was placed in a hemocytometer. In each single partition of the apparatus $\left(1 / 400 \mathrm{~mm}^{2}\right)$ the number of mobile spermatozoa $(\% \%)$ was counted. Besides, at parental forms and their hybrids the length of testis and the vesicular glands was measured as well as the mass of testis, epididymis and vesicular glands.

Copulatory behavior. A copulatory behavior was investigated in 16 males and 16 females of $M$. h. lydius, in total 28 tests was investigated, using the method described above (Dewsbury, 1972; Zorenko \& Malygin, 1983; Zorenko, 1996). All voles were laboratory reared and ranged in age from 3 to 6 mounts.

Mating of voles includes two stages: courtship (latency) and copulation, which consist of a series of mounts, alternating with period of rest. Each series includes mounts with vaginal insertion (intromissions) and intravaginal thrusts and mounts with insertion, thrusting, and sperm transfer (ejaculation). For the copulatory stage, the following indices were recorded: Latency $(\mathrm{Lt})$ - period from introduction of the female until the first intromission; intromission frequency
(IF) — number mounts with intromissions in a copulatory series, not including mount with ejaculation; mean number of thrusts per intromission of a series $(\mathrm{T} / \mathrm{I})$; number of thrusts per ejaculation $(\mathrm{T} / \mathrm{E})$ - number of thrusts during mount with ejaculation; total number of thrusts (NT) - the total number of thrusts during mounts with intromission and ejaculation in a series; duration of copulation (DC) - time interval (s) from the first intromission of a series to the end of ejaculation; postejaculatory interval (PEI) - interval (s) from the end of an ejaculation until the beginning of the next intromission; ejaculation frequency $(\mathrm{EF})$ - number of ejaculations preceding attainment of the 30-min satiety criterion, equal to the number of copulatory series; $\Sigma_{\mathrm{IF}}-$ the total number of intromissions during the whole copulatory period; $\Sigma_{\mathrm{NT}}$ - the total number of thrusts during the mounts with intromission and ejaculation during all the series; $\mathrm{E}_{1 \mathrm{~T}}(\%)$ - percentage of the terminal mounts during whole test which were finished by sperm transfer (ejaculation) after one thrust. During the experiments direct observations and filming with a video camera Logitech HD webcam C270 (1280×720 pixels) were conducted.

Studying of the growth and rate of individual development. The pups were examined daily (until the 15 th day of life). They were weighted $(\mathrm{W}, \mathrm{g})$ and the length of the body $(\mathrm{L}, \mathrm{mm})$, tail $(\mathrm{C}, \mathrm{mm})$ and hind foot $(\mathrm{Pl}, \mathrm{mm})$ were measured. The days of the beginning of the ear formation, incisor teeth eruption, divergence of fingers on extremities and opening of the eyes were scored.

Exploratory behavior. In open-field test 27 males and 27 females $M$. h. lydius were investigated. Every animal was placed in a cylindrical cage with a diameter of $1 \mathrm{~m}$ (which bottom was divided into squares with 0.2 $\mathrm{m}$ side. The field was illuminated by a $60 \mathrm{w}$ bulb suspended $0.9 \mathrm{~m}$ above the center of the open-field. The box $(10 \times 10 \times 7 \mathrm{~cm})$ was placed $5 \mathrm{~cm}$ from the wall of the field. Animals are put into the box in the cylindrical cage and were allowed on a free choice of exit to the arena. During the ten minutes of each experiment the following parameters of animal behavior were registered: horizontal (locomotor) activity was estimated by the number of the squares which were crossed by the vole in every minute, for the two first minutes and in general for $10 \mathrm{~min}$; vertical activity was expressed in rearing (standing on the hind paws and was propping up on the walls of the test arena or on the box or without to propping up), number of urination, defecation, marking of the arena substratum, cleaning (autogrooming), duration of the cleaning and freezing (immovability), time of the first exit from the box (latency) and the first approaching to the center of the open-field where feeder with sunflower seeds and oats grains was placed; number of entries in the box and a climbing on its roof, approach to a feeder, gnawing of various objects and digging. 
Patterns of behavior are united in three groups: locomotor exploring of the space - number of crossing squares (locomotor activity), number of the approaches to a feeder (crossing the field on diagonal), marking on the substratum and rearing on the hind legs without propping; objective exploring of the space entries in the box and climbing on its roof, rearing-up with a support on a box, a gnawing of objects and walls of a field, and digging; emotionality - number of urinations, defecations and cleanings and duration of the cleanings and immobility.

Statistical methods. The statistical data processing was carried out using the program package PAST (Paleontological Statistics; ver. 3.06). Biometric comparison was performed by unpaired Student's t-test for two samples (default settings: "t-Test: Two-Sample Assuming Unequal Variances"). Cluster analysis (Q-mode) single linkage (nearest neighbour) algorithm for dendrogram of similarity of sexual behavior data was used. For the generalized assessment of parameters of behavior of animals in open-field test an index in the equation of Shannon was calculated, which allows to compare two Harting's vole populations, as can be established how often and whether in all individuals each behavior parameter was observed.

$$
\mathrm{H}=-\sum \mathrm{N}_{\mathrm{i}=1} \log ^{2} n_{\mathrm{i}} / \mathrm{N}
$$

where, $\mathrm{N}$ - total number of parameters, $\mathrm{n}_{\mathrm{i}}$ - number of parameters in each group, $\mathrm{m}$ - number of groups.

\section{Results}

Hybridization. Hybridization of males of $M . h$. strandzensis with females of $M$. $h$. lydius was established for all pairs of voles, the litters are small, average of three pups, and as well a third of the offspring not survived to 18-day age (Tab. 1). Percent of mortality is much more in comparison with the survival rate of pups in parental subspecies. Unfortunately, it is not known how females of $M$. $h$. strandzensis would have been hybridized with nonspecific partners as it was not succeeded to trap females of this subspecies for the reciprocal crosses.

The reproductivity of all males of the first generation (3 experiments) and $71.4 \%$ of females was observed. Individuals of F1 are crossbred among themselves and have larger litters but differences are not statistically reliable. A third of pups do not survive to 18 day's age. Besides, many pups were underdeveloped with less body weight; as a result, $21 \%$ of hybrids were dead at the age of 30-45 days (Tab. 1). Thus, the general mortality of offspring of F1 was $53.5 \%$.

Half of males and females from all 20 hybrids of second generation did not participated in breeding. A third of males and $12.5 \%$ of females had litters but all pups dead in the first week of life. Only $16.7 \%$ of males and $37.5 \%$ of females of the offspring was viable and reached mature age. In general, the mortality of the young was the highest - 79.4\% and the intensity of reproduction of $\mathrm{F} 2$ was very low (Tab. 1).

Reproductive ability of F3 hybrids also was not high. From seven hybrids $28.9 \%$ did not breed; $28.9 \%$ had litters, but pups died till 18th day. Only $42.2 \%$ of vole pups survived. Mortality of pups was $63.6 \%$ (Tab. 1). Crossbreeding of hybrids F4 between themselves started in $50 \%$ of pairs. Mortality of the pups of hybrids F4 was decreased to $28.1 \%$.

In the backcrossing of a parental form (M. h. lydius) with hybrids F1 a reproductive activity in $71.4 \%$ of the cases was noted; however, a half of the pups were not viable (Tab. 1). In backcrossing of M. lydius males with females of F2-F5 generations the offspring in $61.5 \%$ of pairs was received and mortality was $55 \%$. In backcrossing of females $M$. lydius with males of F2-F5 generations reproduction only in $55.6 \%$ of cases was noted, and the highest level of mortality - 90.5\% was reached. A little successful breeding took place in crossing of backcross (B1-B2) with hybrids F2-F7. Only in $40 \%$ of pairs, in which the male was backcross, an offspring was received, and the total mortality of young was higher than $50 \%$. If in the pair the female was backcross, the reproduction was established more often, but the offspring also did not survive (Tab. 1). Most of the offspring from these crossing backcrosses (19 individuals in the first crossing type, 16 - in the second one did not breed, or their offspring did not survive; have to be noted that only two males and two females of the offspring were viable and had reached age of mature.

All males of F1 were fertile; however, in $40 \%$ of males F2 spermatozoa were not found. In F3 and F4 the sterility of males was respectively $30 \%$ and $60 \%$. A third of the males of F5 and F6 generations also were sterile (Fig. 1) but in the other males the quantity of spermatozoa in epididymis of testes varied from five to $50 \%$. The smallest content of spermatozoa in backcrosses was noted (Fig. 2). From 65 studied males 27 $(41.5 \%)$ were completely sterile, six had only $5 \%$ of spermatozoa, 29 males had 10 to $30 \%$ spermatozoa $(44.6 \%)$, and $50 \%$ of spermatozoa have been noted only in three males. For comparison the males of $M$. $h$. lydius have had on average $48.9 \pm 3.82 \%(n=14)$ and $M$. h. strandzensis - 50\% $(n=3)$.

The mobility of spermatozoa in epididymis of hybrid males was not high: an average $15 \%$ in males of F1-F7 and 5\% in backcross males have been noted. For comparison males of $M$. h. lydius have had from 25 to $50 \%$ of mobile spermatozoa (on average $36.8 \%$ ).

Indicators of male reproductive system. The investigated subspecies of Harting's vole credibly differ in the relative mass of testes and their epididymis in spite of the fact that on males' body weight does not differ. All indicators of reproductive organs in males of $M$. h. lydius are greater, than in M. h. strandzensis. Moreover, the vesicular glands in males of the second subspecies was about 1.7 times lighter, then in the first one. Evidence suggests the species-specificity of these indicators. In F1-F6 hybrids the mass of testes and 


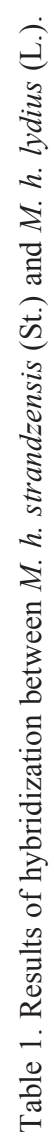

\begin{tabular}{|c|c|c|c|c|c|c|c|c|c|c|c|c|}
\hline 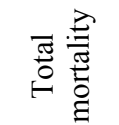 & & & $\stackrel{+}{\stackrel{f}{f}}$ & $\begin{array}{l}n \\
n \\
n\end{array}$ & 访 & ণั & $\begin{array}{l}0 \\
\text { ఠ் }\end{array}$ & $\vec{\infty}$ & $\frac{9}{\gamma}$ & "n & $\underset{n}{n}$ & $\begin{array}{l}\infty \\
\underset{f}{f}\end{array}$ \\
\hline 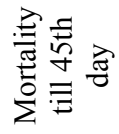 & & & 0 & $\hat{\stackrel{N}{े}}$ & $\begin{array}{l}\infty \\
\text { i }\end{array}$ & 0 & 0 & $\vec{m}$ & 0 & $\stackrel{\infty}{+}$ & $\begin{array}{l}\dot{0} \\
\stackrel{\sim}{\sim}\end{array}$ & $\vec{r}$ \\
\hline 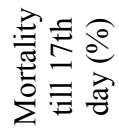 & $\theta$ & $\begin{array}{l}0 \\
\stackrel{1}{I}\end{array}$ & $\stackrel{+}{\stackrel{f}{f}}$ & $\begin{array}{l}0 \\
\text { d }\end{array}$ & $\frac{\vec{\Delta}}{\dot{n}}$ & 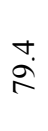 & 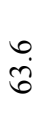 & $\stackrel{0}{a}$ & $\stackrel{9}{\dot{\gamma}}$ & $\vec{\infty}$ & $\begin{array}{l}0 \\
\infty \\
\infty \\
n\end{array}$ & in \\
\hline
\end{tabular}

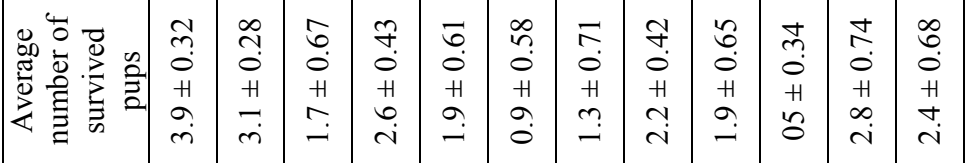

\begin{tabular}{|c|c|c|c|c|c|c|c|c|c|c|c|}
\hline 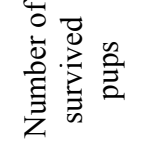 & $\underline{6}$ & $\stackrel{2}{\beth}$ & $ㅇ$ & নे & $I$ & $r$ & $\infty$ & $\stackrel{\Xi}{\sim}$ & $\ddot{\sim}$ & $n$ & $\approx$ \\
\hline 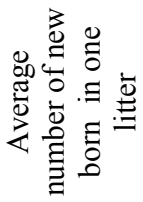 & $\begin{array}{l}\stackrel{n}{a} \\
0 \\
+1 \\
\stackrel{+}{+}\end{array}$ & $\begin{array}{l}\text { ra } \\
0 \\
H \\
b \\
\dot{n}\end{array}$ & $\begin{array}{l}n \\
n \\
0 \\
+1 \\
0 \\
\dot{n}\end{array}$ & $\begin{array}{l}\vec{m} \\
0 \\
H \\
\hat{n} \\
\dot{m}\end{array}$ & $\begin{array}{l}\vec{n} \\
0 \\
+1 \\
\dot{m}\end{array}$ & $\begin{array}{l}\hat{n} \\
0 \\
H \\
\text { r } \\
\forall\end{array}$ & $\begin{array}{l}\vec{n} \\
0 \\
+1 \\
\ddot{n}\end{array}$ & 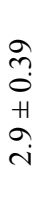 & 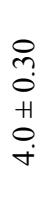 & $\begin{array}{l}0 \\
+ \\
0 \\
+1 \\
n \\
n\end{array}$ & $\begin{array}{l}0 \\
+ \\
+ \\
0 \\
+ \\
0 \\
\dot{+}\end{array}$ \\
\hline
\end{tabular}

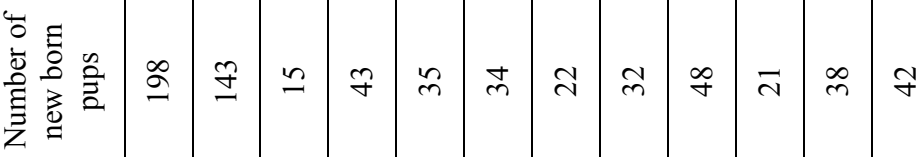

\begin{tabular}{|c|c|c|c|c|c|c|c|c|c|c|c|}
\hline 0 & it & $m$ & $\approx$ & $\stackrel{\Omega}{\Omega}$ & $\vec{a}$ & 0 & $\infty$ & 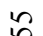 & $\curvearrowleft$ & 2 & 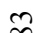 \\
\hline 0 & $\because$ & $\because$ & - & $\because$ & $\dot{\forall}$ & 6 & in & $\ddot{\forall}$ & $\dot{m}$ & in & $\dot{\nabla}$ \\
\hline$\sqrt[n]{6}$ & $\begin{array}{l}H \\
0\end{array}$ & $\stackrel{H}{m}$ & ${ }_{\infty}^{H}$ & $\begin{array}{l}H \\
n\end{array}$ & ${ }_{\infty}^{+}$ & $\stackrel{H}{\mathrm{~N}}$ & $H_{0}^{H}$ & $\stackrel{H}{0}$ & $\#$ & $\stackrel{H}{N}$ & ${ }_{0}^{H}$ \\
\hline$\tilde{\sigma}^{0}$ & $\ddot{n}$ & $\dot{m}$ & $\stackrel{d}{d}$ & $\tilde{N}$ & 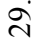 & $\dot{m}$ & $\dot{n}$ & ri & $\dot{m}$ & $\stackrel{\infty}{+}$ & $\dot{n}$ \\
\hline
\end{tabular}

\begin{tabular}{|c|c|c|c|c|c|c|c|c|c|c|c|c|}
\hline 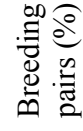 & 8 & 8 & 8 & $\vec{n}$ & $\stackrel{+}{\stackrel{+}{R}}$ & $\stackrel{\circ}{\circ}$ & $\tilde{\sigma}$ & 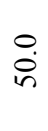 & $\stackrel{m}{8}$ & $\begin{array}{l}0 \\
\dot{n} \\
i n\end{array}$ & $\begin{array}{l}\dot{q} \\
\dot{q}\end{array}$ & $\frac{7}{6}$ \\
\hline 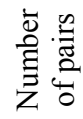 & $\mathcal{F}$ & $F$ & $m$ & $r$ & $r$ & 으 & $\infty$ & 0 & $\Xi$ & $a$ & 으 & $\stackrel{\infty}{-}$ \\
\hline 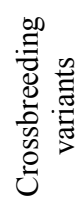 & $\begin{array}{l}\dot{\omega} \\
\text { O+ } \\
\times \\
\dot{\infty} \\
\dot{\infty} \\
\overline{0}\end{array}$ & 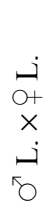 & $\begin{array}{l}\dot{\vec{j}} \\
\dot{O+} \\
\times \\
\dot{\omega} \\
\dot{\tilde{\omega}} \\
\overline{0}\end{array}$ & $\begin{array}{l}\vec{I} \\
\times \\
\vec{x}\end{array}$ & $\begin{array}{l}\overrightarrow{\mid r} \\
\times \\
\dot{x}\end{array}$ & $\begin{array}{l}\underset{I}{N} \\
\times \\
\underset{I}{\times}\end{array}$ & $\begin{array}{c}\stackrel{M}{ } \\
\times \\
\cong\end{array}$ & $\begin{array}{l}\vec{I} \\
\times \\
\underset{L}{+}\end{array}$ & 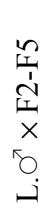 & 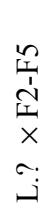 & $\begin{array}{c}0 \\
0 \\
1 \\
1 \\
I \\
0+ \\
\times \\
50 \\
0\end{array}$ & $\begin{array}{l}6 \\
1 \\
1 \\
\text { I } \\
1 \\
0 \\
0 \\
\times \\
0+ \\
0\end{array}$ \\
\hline
\end{tabular}




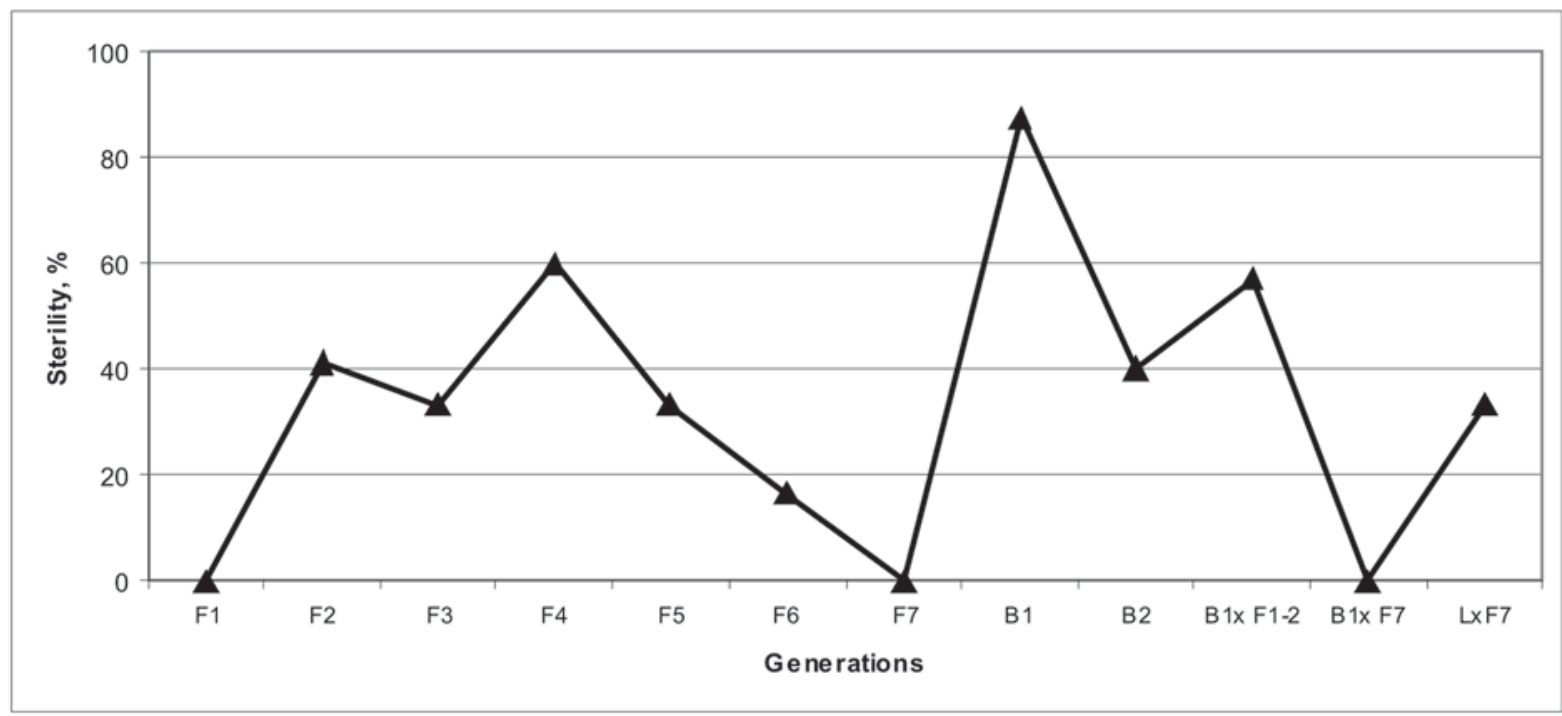

Fig. 1. Sterility (\%\%) of hybrid males F1-F6 generations, backcrosses (B1, B2), backcrosses B1/hybrids F1, F2, backcrosses B1/hybrids F7, backcrosses B2/hybrids F7, and parental subspecies L. (M. h. lydius: male/female)/hybrids F7.

epididymis decreases and was credibly lower, than in males of $M$. h. lydius $(p<0.001)$, but closer to that of M. h. strandzensis (Tab. 2). The smallest indicators in hybrids of F1-F2 and backcross B1 were obtained, then in F3-F6 hybrids the mass of testes and epididymis have increase which correlated with the increasing of their reproductive ability.

All hybrid males are divided into two groups; in the first group $(58.5 \%)$ testes and epididymis slightly differ from that in $M$. h. strandzensis. The spermatogenesis process was not stopped; however its intensity was reduced. The reduced concentration of spermatozoa in epididymis testifies about it: in hybrids on average about $20 \%$ and in backcrosses $10 \%$. Only in some males of F5-F6 generations a concentration of spermatozoa reaches $50 \%$. In the second group of males $(41.5 \%)$ spermatozoa in epididymis were not found or their contents did not exceed 5\%. Low value of indicators of testes and epididymis testified for bigger extent of a spermatogenesis disorder. The percentage of such males is especially great in backcrosses (Fig. 1; Tab. 2).

Mating behavior. After housing the voles together, the identification of sex and a physiological condition of the females by the males is noted. It promotes overcoming of fear, synchronization of partners' behavior and defines successful mating. This phase of contacts is defined as courtship or "a latent phase of copulation" (last terms is often used in literature - see Dewsbury, 1972). During the courtship, the animals sniffing and follow each to other and demonstrate an increased interest to anal-genital region of the partner. In the period of exploration of the territory, where the receptive female was found, males of both subspecies marked her using urinary traces on the substrate. The intensity of the marking depends on the level of sexual activity of males. In a lot of vole species, the synchronization of behavior of the partners is promoted by so-called "waltzing" of the males and the stimulating running of females. The females show receptivity by taking up the posture of lordosis, often persecuted by the males. However, waltzing of the males of $M$. $h$. lydius (and $M$. $h$. strandzensis) is weak, more often courtship manifests itself in the form of mutual running. The males of Harting's vole in comparison with other vole species did not sound so called "sexual singing". After housing the voles together naso-nasal (oral) and naso-anal sniffing, following each other, rarely grooming are observed. Behavior patterns of the males for identification twice prevail over those of the females, which could be explained with their desire to determine the females' receptivity for mating.

Considerable individual variability of courtship or latency was noted. Latent period of copulation of $M$. $h$. lydius continues from 100 to $1410 \mathrm{~s}$ (Tab. 3). Only 30\% of studied males were begun copulation during the first three minutes. Most males initiate the first copulations at seven to $20 \mathrm{~min}$. In addition, $M$. $h$. lydius voles demonstrate desire to mate only with familiar partners. A housing of unfamiliar individuals can not lead to mating within $60 \mathrm{~min}$ or not at all. Copulation in $M . h$. lydius consists of 3-5 series of stereotypic units and finished after attainment the satiety in male and copulation finished. The number of the series usually corresponds to the number of the ejaculations, although in rare cases the last series could not be completed with ejaculation which was due to fatigue of the male. Typically, males make four to nine mounts with intromission before the ejaculation. Number of intromissions in one series was the most variable component as well in the same males and in the various males too. Over the entire period of mating from 13 to 32 intromissions were made (Tab. 3). 


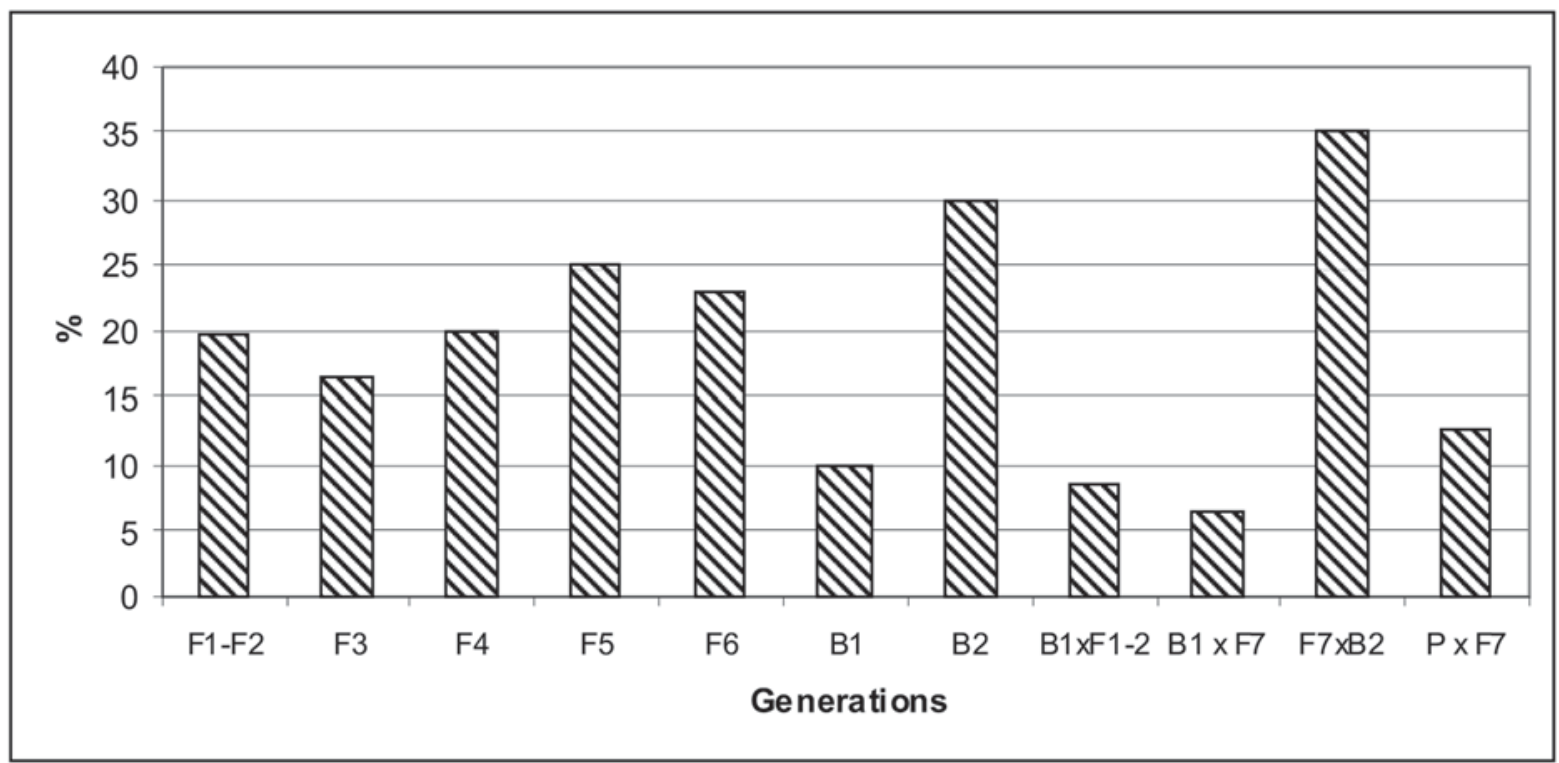

Fig. 2. Relative content of spermatozoa (in \%) in the epididymis of F1-F6 hybrid generations, in the backcrosses and in different versions of crossing between backcrosses B1 and B2 and hybrids F1-2 and F7; the last version is the crossing M.h.lydius male and hybrids F7.

Each mount with intromission consists of 1-4 thrusts; during the mounts with ejaculation $M . h$. lydius usually makes one thrust, rarely two or three. Number of the thrusts per series remarkably varies - from 6 to 28 and on average from 20 to 80 for the entire copulation period (Tab. 3). The duration of each series of mating varies from 50 to $150 \mathrm{~s}$. This value depends on the individual behavior of the male. Mating process requires more time and energy costs from the animals (especially from the males). Therefore, when the series were completed the voles have a rest for a few minutes before the next mating series. First part of the postejaculatory phase was manifested in the form of long grooming and short sleep. Then the rest part was replaced by a new activity of animals and the behavior was similar to a courtship and preparation for the next series of copulation. Generally, during the mating period of $M$. h. lydius three, rarely four post-ejaculatory intervals were noted. After each successive series males needed more time for restoration of the sexual function. The second PEI was prolonged by an average of 1.7 times (1.5 to 2 ) compared with the first one. If third series of mating was observed, animals rest for 15 to 20 minutes. Duration of the entire period of copulation takes about 30 to 40 minutes.

Asian $M . h$. lydius form of voles differs from European $M$. $h$. strandzensis form in all quantitative parameters characterizing the copulation stereotype. It was distinguished by larger number of ejaculations and total number of intromissions for each series and for the entire period of mating (Tab. 3). The latent period and the mating series of lydius were longer but significant differences only for the latter ones were established. The post-ejaculatory interval in $M$. $h$. lydius was short- er. The genital stimulation in each series in both forms was similar but the overall level of stimulation till attainment of the satiety in Asian form in comparison with the European's one was 1.4 times higher.

Cluster analysis based on the indicators of sexual behavior showed the special place of $M$. $h$. lydius in the subgenus Sumeriomys quite far from M. h. strandzensis, which indicates a significant divergence between the Asian and European populations (Fig. 3).

Growth and development of Harting's vole. The results of studying of the growth and rate of individual development showed that the number of the pups in the litter was similar and at $M . h$. lydius was $4.3 \pm 0.47$ and at $M$. h. strandzensis was $4.6 \pm 0.68$ pups. The weight of newborn pups $M$. h. lydius was averages $3.1(2.4-3.7) \mathrm{g}$ and body length of $40.7(35.0-44.0) \mathrm{mm}$. They grow quickly, reaching on the 15 th day about eight to $12 \mathrm{~g}$ (Tab. 4), although individual differences could be substantial. The specific rate of increase of the body weight of $M$. h. lydius for the first ten days had been $9.1 \%$, and from 10 to 15 th day $-3.7 \%$, respectively. For $M$. $h$. strandzensis these values had been eight and $5.64 \%$, i. e. the dynamics of growth in the two forms was different. In the first form particularly intensive growth from 5 to 10th days was observed, while for the second from 10 to 15 days. Pups doubled their weight for 30 days, then the growth slows and on two months' age it was increased only by $10 \%$. The growth of Harting's voles continues to five months' age. The increase of the weight and body length of the $M . h$. lydius pups significantly faster in comparison with $M$. $h$. strandzensis was found. The length of the hind foot and tail of $M . h$. lydius were increased noticeably faster (Tab. 4). Specific rate of the growth of the hind foot for the period of 
Table 2. The absolute and relative weight of testis and epididymis in males of investigated $M$. hartingi subspecies and their hybrids.

\begin{tabular}{|c|c|c|c|}
\hline $\begin{array}{c}\text { Subspecies and its } \\
\text { hybrids }\end{array}$ & $\mathrm{N}$ & $\begin{array}{l}\text { Absolute weight (mg) } \\
\text { relative weight of testis }\end{array}$ & $\begin{array}{l}\text { Absolute weight }(\mathrm{mg}) \text { relative } \\
\text { weight of epididymis }\end{array}$ \\
\hline M. h. lydius & 19 & $\begin{array}{c}391.7 \pm 20.34^{*} \\
0.79 \pm 0.04^{*}\end{array}$ & $\begin{array}{c}32.4 \pm 2.09^{*} \\
0.07 \pm 0.004 *\end{array}$ \\
\hline M. h. strandzensis & 26 & $\begin{array}{c}228.0 \pm 23.73 \\
0.42 \pm 0.04\end{array}$ & $\begin{array}{c}21.1 \pm 2.19 \\
0.02 \pm 0.002\end{array}$ \\
\hline $\mathrm{F} 1-\mathrm{F} 2$ & 19 & $\begin{array}{c}195.2 \pm 31.76 \\
0.39 \pm 0.05\end{array}$ & $\begin{array}{c}13.9 \pm 2.48 \\
0.03 \pm 0.004\end{array}$ \\
\hline F3 & 6 & $\begin{array}{c}205.2 \pm 70.51 \\
0.48 \pm 0.14\end{array}$ & $\begin{array}{l}16.3 \pm 4.43 \\
0.04 \pm 0.01\end{array}$ \\
\hline F4-F5 & 8 & $\begin{array}{c}283.9 \pm 67.72 \\
0.52 \pm 0.11\end{array}$ & $\begin{array}{l}15.0 \pm 4.53 \\
0.03 \pm 0.01\end{array}$ \\
\hline F6-F7 & 7 & $\begin{array}{c}270.1 \pm 28.51 \\
0.60 \pm 0.05\end{array}$ & $\begin{array}{l}24.6 \pm 3.57 \\
0.05 \pm 0.01\end{array}$ \\
\hline B1 & 15 & $\begin{array}{c}157.5 \pm 31.71 \\
0.36 \pm 0.06\end{array}$ & $\begin{array}{c}10.3 \pm 2.28 \\
0.02 \pm 0.005\end{array}$ \\
\hline B2 & 4 & $\begin{array}{c}244.5 \pm 87.92 \\
0.66 \pm 0.18\end{array}$ & $\begin{array}{l}15.5 \pm 5.04 \\
0.05 \pm 0.01\end{array}$ \\
\hline $\mathrm{B} \times \mathrm{F} 7$ & 4 & $\begin{array}{c}295.2 \pm 52.04 \\
0.68 \pm 0.08\end{array}$ & $\begin{array}{l}22.0 \pm 4.71 \\
0.05 \pm 0.01\end{array}$ \\
\hline L. $\times$ F7 & 3 & $\begin{array}{c}294.7 \pm 38.98 \\
0.92 \pm 0.03 \\
\end{array}$ & $\begin{array}{l}15.0 \pm 3.79 \\
0.04 \pm 0.01\end{array}$ \\
\hline 1 st. group of hybrids & 38 & $\begin{array}{c}303.4 \pm 15.19^{*} \\
0.65 \pm 0.03 *\end{array}$ & $\begin{array}{c}22.3 \pm 1.27^{*} \\
0.05 \pm 0.003^{*}\end{array}$ \\
\hline 2nd. group of hybrids & 27 & $\begin{array}{l}88.2 \pm 15.36 \\
0.24 \pm 0.03\end{array}$ & $\begin{array}{c}5.4 \pm 0.89 \\
0.02 \pm 0.003\end{array}$ \\
\hline
\end{tabular}

Abbreviations: $*-p<0.001 ; 1$ st group of hybrids — the spermatogenesis process was not stopped. However, its intensity was reduced; 2nd group of hybrids - spermatozoa in epididymis were not found or their contents did not exceed 5\%. The comparisons between males of the two investigated subspecies and two groups of hybrids were made. Also see abbreviations in Tab. 1.

one to 10 th days was 6.42 and $5.72 \%$ of the two forms respectively. On the contrary, the tail of $M$. $h$. strandzensis grows faster (respectively 6.3 and $7.64 \%$ ).

The exterior signs formation of of the two taxa on different specific rates was established. In the young of $M$. $h$. lydius the ear formation, incisor teeth eruption, disseverance of the extremities fingers and opening of the eyes was begun earliar (Tab. 5). The M.h. strandzensis compared with these from the Asian part of the area were develop slower.

Exploratory behavior. In the open-field tests of males of $M$. $h$. lydius the locomotor activity demonstrated was low. Half of males crossed only 10 to 50 squares and a half -51 to 90 squares in the first two minutes. It is interesting to note that $78 \%$ females do not cross more 50 squares. In the next eight minutes voles dramatically reduced their movement and begun to get away from the wall of the field, gradually ap- proaching to the center or permanently were freezing. During the entire experiment, females of $M$. $h$. lydius passed distance an average $18.1 \pm 2.09 \mathrm{~m}$, males of $M . h$. lydius $28.7 \pm 2.68 \mathrm{~m}$, while males of $M$. h. strandzensis $61.6 \pm 6.72 \mathrm{~m}$, i.e. 2.1 times more. Vertical activity of $M$. $h$. lydius (a number of rearing) was lower than in males' M. h. strandzensis, too (Tab. 6). A correlation between locomotion and rearing is not fixed.

A typical feature of the behavior of $M$. $h$. lydius was a long immobility near the wall of the field or inside the box. Half of males and $69 \%$ of females freeze more two minutes (100-360 s). Immobility was a specific less for M. h. strandzensis and only $16 \%$ of males freeze for 2 to 3 minutes. Although a number of auto-grooming was not different in both subspecies, duration was significantly greater in males and females of $M$. $h$. lydius (Tab. 6).

Although males of $M$. $h$. lydius cross a center of the cage and approach the feeder faster, the number of 
Table 3. Quantitative parameters $(\mathrm{M} \pm \mathrm{m})$ of mating behavior in the investigated $M$. hartingi subspecies.

\begin{tabular}{|l|c|c|c|}
\hline \multicolumn{1}{|c|}{ Parameters } & $\begin{array}{c}\text { M. h. lydius } \\
n=28\end{array}$ & $\begin{array}{c}\text { M. h. strandzensis } \\
\text { (Zorenko, 2000) } \\
n=25\end{array}$ & Student's t-test \\
\hline EF & $3.5 \pm 0.16$ & $3.0 \pm 0.16$ & $\mathrm{t}=2.17^{*}$ \\
\hline$\Sigma_{\mathrm{IF}}$ & $29.6 \pm 2.76$ & $11.5 \pm 1.40$ & $\mathrm{t}=5.84^{* * *}$ \\
\hline$\Sigma_{\mathrm{NT}}$ & $52.6 \pm 4.01$ & $36.6 \pm 3.61$ & $\mathrm{t}=2.97^{* *}$ \\
\hline $\mathrm{E}_{\mathrm{IT}}(\%)$ & $82.7 \pm 4.03$ & $31.5 \pm 4.81$ & $\mathrm{t}=8.18^{* * *}$ \\
\hline IF, 1st. series & $6.1 \pm 0,40$ & $3.5 \pm 0.34$ & $\mathrm{t}=5.00^{* * *}$ \\
\hline T/I, 1st. series & $1.9 \pm 0.11$ & $3.0 \pm 0.28$ & $\mathrm{t}=3.14^{* *}$ \\
\hline T/E, 1st. series & $1.2 \pm 0,11$ & $3.0 \pm 0,29$ & $\mathrm{t}=6.00^{* * *}$ \\
\hline NT, 1st. series & $12.9 \pm 1.01$ & $12.4 \pm 0.73$ & $\mathrm{insufficient} \mathrm{diff.}$ \\
\hline DC (s) & $74.9 \pm 5.12$ & $53.0 \pm 4.67$ & $\mathrm{t}=3.17^{* * *}$ \\
\hline PEI (s) & $346.7 \pm 23.14$ & $452.4 \pm 40.00$ & $\mathrm{t}=2.29 *$ \\
\hline Lt (s) & $413.0 \pm 70,31$ & $294.2 \pm 75.36$ & $\mathrm{t}=1.15$ \\
\hline
\end{tabular}

Abbreviations: $*-p<0.05 ; * *-p<0.01 ; * * *-p<0.001$. Also see text.

these approximations is less than that of males of $M . h$. strandzensis (Tab. 6). It is interesting to note that this index in females of $M$. $h$. lydius $(352.9 \pm 47.14 \mathrm{~s})$ is 4.4 times more, then in males. A correlation between locomotor activity and frequency of approaching to a center (M. h. lydius, $r=0.49$ and $M$. h. strandzensis, $r=0.36$ ) was established. Only $25.9 \%$ of the $M$. $h$. lydius males and females were started to eat food, whereas $30 \%$ of males of $M$. $h$. strandzensis were feed. Graphs show that $M . h$. strandzensis greatly diverge from $M . h$. lydius (Fig. 4) on these indices as locomotion, duration of immobility, vertical activity and autogrooming. The males of lydius intensively demonstrate exploring of objects: entries in box, rearing on the box, it's gnawing and digging, compared with these of $M$. h. strandzensis.

The frequency of urination, defecation and marking of territory by urine in males of $M$. $h$. lydius also were lower, compared with these of $M$. h. strandzensis, but significantly differs only in the intensity of marking behavior of the arena (Tab. 6). A correlation of urination and locomotion was not noted, but a little negative correlation for defecation and locomotion was shown only in $M$. $h$. strandzensis $(r=-0.28)$.

The comparison of the overall index (Shannon's index) of the two populations of $M$. harting $i$ a significant difference was shown. By novel stimuli a locomotor exploring of the space is more expressed in $M . h$. strandzensis, while in $M . h$. lydius this rate is lower (Fig. 5). The opposite trend for the index of the objective exploring of space, which in $M$. $h$. lydius was significantly higher than in $M$. h. strandzensis, was noted. The voles $M$. $h$. lydius in the open-field test were with higher emotionality than $M$. h. strandzensis (Fig.
5). For comparison it could be noted that in $M$. socialis the emotional index varies depending on the subspecies from 1.2 to 2.2 (i.e. $1.2-2$ times higher) whereas in $M$. paradoxus almost three times (2.8). Only the species $M$. schidlovskii showed different emotionality with the lowest level of the emotional index (0.7) (Zorenko, 2013).

\section{Discussion}

The results of experimental hybridization violations of spermatogenesis in all hybrid males were revealed and a significant proportion of hybrids spermatozoa were completely missing or had a lesser content of spermatozoa or the percentage of motile spermatozoa were markedly reduced. Reducing the number and motility of spermatozoa significantly reduces their ability for fertilization (Zhabin et al., 2010).

Accordingly, a difference in the indicators of the gonads was noted. Among the hybrids two groups were found. In the first group of males the parameters of the size and weight of genitals were similar to those of males of $M$. h. strandzensis, but the observed differences were not significant. The differences were significantly less in comparison with the males of $M$. h. lydius (Tab. 2). Low weights of the testes and their appendages were found in all obtained generations of hybrid males and backcrosses, despite the fact that there were only backcross individuals with $M$. $h$. lydius. These males retain the ability for reproducing and the sperm concentration in the epididymis, although reduced in comparison with the parental forms, but provides the probability of fertilization of females. In the second 


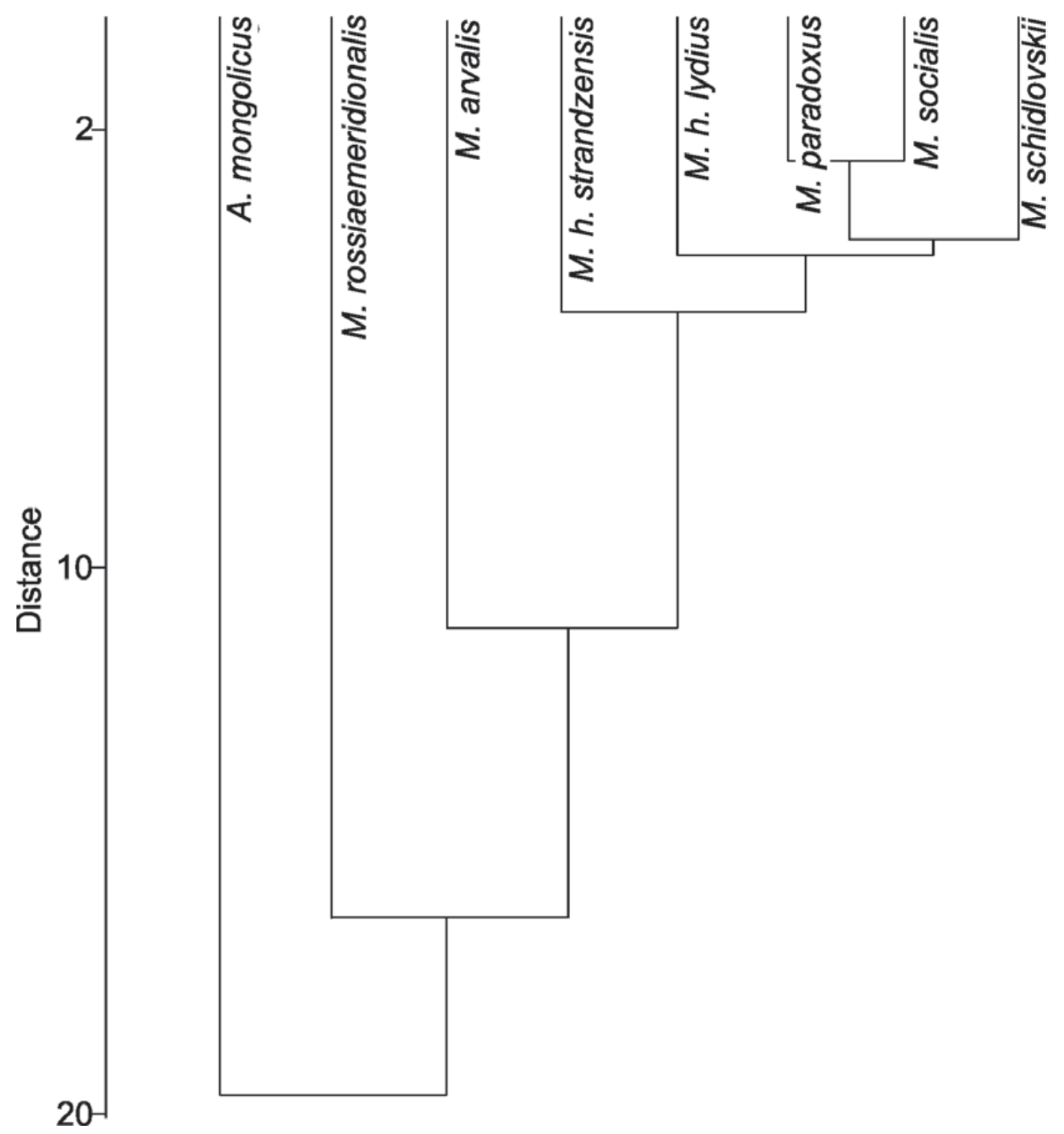

Fig. 3. Nearest neighbor similarity dendrogram (single linkage) of the indicators of sexual behavior of some vole taxa.

group of hybrids genitals were underdeveloped, the epididymis virtually missing. These males lost the ability to reproduce.

The number of young in all pairs of hybrid voles compared to the parental taxa was reduced. Particular note was the high mortality of young from the first three generations of hybrids. Although, the F1 hybrids were quite viable for reproduce, their offspring were often not viable, sub viable, semi-sterile or sterile. They could be regarded as unsuccessful products of recombination produced by hybridization of the two taxa. Obviously, there was a suppression of the potential and the fertility of the hybrid offspring, i.e., "hybrid destruction" (hybrid breakdown). The real reason for the sterility of hybrids of the males $M$. hartingi subspecies is not investigated, but it was shown that for the wild mouse
Mus musculus domesticus chromosomal races, it was the non-disjunction of rearranged chromosomes and formation of unbalanced gametes (Castiglia \& Capanna 2000), while the hybrids of South American punare Thrichomys pachyurus Wagner, 1845, T. apereoides Lund, 1939 subsp. apereoides and T. apereoides subsp. laurentius showed a decreased number of spermatogonia and primary spermatocytes due to held meiosis before and during prophase (Borodin et al., 2006). In our case the second reason may be more significant. The sterility observed among backcrossed males is especially high (Fig. 1) that indicates for genetic incompatibility (Borodin et al., 2006).

The observed sterility among backcrossed males is especially high (Fig. 1) which indicates a genetic incompatibility (Borodin et al., 2006). 
Table 4. Exterior parameters $(\mathrm{M} \pm \mathrm{m})$ of the pups of the investigated $M$. hartingi subspecies in the early postnatal period of ontogenesis.

\begin{tabular}{|c|c|c|c|c|}
\hline Age, days & Signs & M. h. lydius & $\begin{array}{c}\text { M. h. strandzensis } \\
\text { (Golenishchev et al., 1991) }\end{array}$ & $\begin{array}{l}\text { Student } \\
\text { coefficient }\end{array}$ \\
\hline \multirow{4}{*}{1} & $\mathrm{~W}^{1}$ & $3.48 \pm 0.07(50)$ & $3.11 \pm 0.06(79)$ & $4.0 * * *$ \\
\hline & $\mathrm{L}^{2}$ & $43.66 \pm 0.38(50)$ & $40.37 \pm 0.28(79)$ & $7.0 * * *$ \\
\hline & $\overline{\mathrm{Pl}^{3}}$ & $7.54 \pm 0.06(50)$ & $7.06 \pm 0.05(79)$ & $6.2 * * *$ \\
\hline & $\mathrm{C}^{4}$ & $7.88 \pm 0.09(50)$ & $6.79 \pm 0.07(79)$ & $9.6 * * *$ \\
\hline \multirow{4}{*}{5} & $\mathrm{~W}$ & $5.61 \pm 0.11(52)$ & $4.95 \pm 0.09(62)$ & $4.6^{* * *}$ \\
\hline & $\mathrm{L}$ & $52.52 \pm 0.39(52)$ & $50.18 \pm 0.38(62)$ & $4.3 * * *$ \\
\hline & $\mathrm{Pl}$ & $10.17 \pm 0.12(52)$ & $9.19 \pm 0.09(62)$ & $6.5^{* * *}$ \\
\hline & $\mathrm{C}$ & $10.77 \pm 0.16(52)$ & $8.83 \pm 0.12(62)$ & $9.7 * * *$ \\
\hline \multirow{4}{*}{10} & $\mathrm{~W}$ & $8.32 \pm 0.12(59)$ & $6.61 \pm 0.13(86)$ & $9.7 * * *$ \\
\hline & $\mathrm{L}$ & $62.83 \pm 0.42(59)$ & $56.64 \pm 0.39(86)$ & $10.8^{* * *}$ \\
\hline & $\mathrm{Pl}$ & $13.67 \pm 0.11(59)$ & $11.86 \pm 0.09(86)$ & $5.8^{* * *}$ \\
\hline & $\mathrm{C}$ & $14.06 \pm 0.13(59)$ & $11.78 \pm 0.10(86)$ & $14.2^{* * *}$ \\
\hline \multirow{4}{*}{15} & $\mathrm{~W}$ & $9.73 \pm 0.87(65)$ & $8.78 \pm 0.27(54)$ & 1.0 \\
\hline & $\mathrm{L}$ & $68.24 \pm 0.47(65)$ & $65.72 \pm 0.7(54)$ & $2.9^{* *}$ \\
\hline & $\mathrm{Pl}$ & $15.36 \pm 0.77(65)$ & $14.02 \pm 0.17(54)$ & 1.7 \\
\hline & $\mathrm{C}$ & $16.10 \pm 0.77(65)$ & $13.91 \pm 0.17(54)$ & $2.8 * *$ \\
\hline
\end{tabular}

Abbreviations: W — body weight (g); L — body length (mm); PL — hindfoot length (mm); C — tail length $(\mathrm{mm})$. Also see Abbr. in Tab. 3.

Table 5. Development of the exterior morphological features of the pups of $M . h . l y d i u s$ and $M . h$. strandzensis in the early postnatal period of ontogenesis. Statistical information is in the following: $\mathrm{M} \pm \mathrm{m}$, limits in parenthesis.

\begin{tabular}{|l|c|c|c|}
\hline \multicolumn{1}{|c|}{ Signs } & $\begin{array}{c}\text { M. h. lydius } \\
(\mathrm{n}=58)\end{array}$ & $\begin{array}{c}\text { M. h. strandzensis } \\
(\mathrm{n}=30)\end{array}$ & Student's t-test \\
\hline Ear formation, days & $\begin{array}{c}2.6 \pm 0.06 \\
(2-4)\end{array}$ & $\begin{array}{c}3.3 \pm 0.13 \\
(2-4)\end{array}$ & $\mathrm{t}=5.0^{* * *}$ \\
\hline Cutting of lower incisors, days & $\begin{array}{c}5.2 \pm 0.11 \\
(4-6)\end{array}$ & $\begin{array}{c}5.5 \pm 0.10 \\
(4-5)\end{array}$ & $\mathrm{t}=2.5^{* *}$ \\
\hline Cutting of upper incisors, days & $\begin{array}{c}5.7 \pm 0.12 \\
(5-7)\end{array}$ & $\begin{array}{c}6.0 \pm 0.11 \\
(5-7)\end{array}$ & $\mathrm{t}=1.9^{*}$ \\
\hline Divergence of fingers on & $\begin{array}{c}8.0 \pm 0.14 \\
(7-9)\end{array}$ & $\begin{array}{c}8.9 \pm 0.12 \\
(7-10)\end{array}$ & $\mathrm{t}=5.0^{* * *}$ \\
\hline forelimbs, days & $\begin{array}{c}10.1 \pm 0.13 \\
(8-12)\end{array}$ & $\begin{array}{c}11.0 \pm 0.15 \\
(9-13)\end{array}$ & $\mathrm{t}=4.5^{* * *}$ \\
\hline foot, days & $\begin{array}{c}10.8 \pm 0.09 \\
(10-12)\end{array}$ & $\begin{array}{c}11.9 \pm 0.22 \\
(10-13)\end{array}$ & $\mathrm{t}=4.6^{* * *}$ \\
\hline Opening of eyes, days & & & \\
\hline
\end{tabular}

Abbreviations see in Tab. 3.

The results of experimental hybridization a substantial degree of divergence of species of the subgenus social voles Sumeriomys have been showed. These could be traced, at least in several demonstrated versions (Zorenko, 2013). Crossbreeding of species of the group "guentheri" (M. hartingi, M. guentheri and $M$. qazvinensis Golenishchev et al., 2003), on the one hand, and species of the group "socialis" (M. socialis Pallas, 1773, M. paradoxus Ognev et Heptner, 1928, and M. schidlovskii Argyropulo, 1933), on the other, had as result sterile hybrids of both sexes or only sterile hybrids male (Zorenko et al., 1997; Golenishchev et al., 2002; Golenishchev et al., 2003; Golenishchev \& Abramson, 2011; Golenishchev \& Malikov, 2011). Hybrids were with significantly reduced weight of the testes and epididymis, as well as of the additional sexual glands, the spermatogenesis and oogenesis were disrupted. This was an example for final forming of postzygotic isolation of species.

The second variant of postzygotic insulation was a partial sterility of the hybrid offspring. In accordance with the Haldane rule, sterile were been only males. Partial male sterility by crossing of $M$. schidlovskii with M. socialis was been noted (Zakharyan, 1958; Akhverdyan et al., 1991; Makaryan et al., 1991; Golenishchev et al., 2002). Special attention should be paid to $M$. qazvinensis which after the hybridization provide sterile hybrid males and fertile females as a result of hybridization with the "guentheri" group (M. g. philistinus) and with the group "socialis" - M. socialis (Go- 
Table 6. Indicators of exploratory behavior of the two M. hartingi subspecies in the open-field test.

\begin{tabular}{|l|c|c|c|}
\hline \multicolumn{1}{|c|}{ Indicators of behavior } & $\begin{array}{c}\text { M. h. lydius } \\
\text { males } \\
n=27\end{array}$ & $\begin{array}{c}\text { M. h. lydius } \\
\text { females } \\
n=27\end{array}$ & $\begin{array}{c}\text { M. h. strandzensis } \\
\text { (Zorenko, 2013) } \\
\text { males } \\
27\end{array}$ \\
\hline Latency (s) & $7.5 \pm 1.83$ & $5.3 \pm 1.70$ & $20.1 \pm 5.02^{*}$ \\
\hline Locomotory activity (LA) & $144.4 \pm 12.49$ & $90.0 \pm 10.48^{* * *}$ & $317.9 \pm 36.76^{* * *}$ \\
\hline LA for the two first minutes & $53.0 \pm 4.05$ & $34.5 \pm 4.39^{* * *}$ & $72.7 \pm 6.94^{*}$ \\
\hline Immobility (s) & $121.1 \pm 18.83$ & $222.3 \pm 23.15^{* * *}$ & $46.6 \pm 16.32^{* *}$ \\
\hline Duration of autogroming (s) & $73.9 \pm 13.24$ & $70.6 \pm 11.18$ & $19.6 \pm 1.53^{* * *}$ \\
\hline $\begin{array}{l}\text { First approaching to the center of the } \\
\text { open-field (s) }\end{array}$ & $79.8 \pm 16.90$ & $352.9 \pm 47.14^{* * *}$ & $111.2 \pm 23.89$ \\
\hline Number of approaching to the center & $6.9 \pm 0.91$ & $3.2 \pm 0.78^{* * *}$ & $16.0 \pm 2.04^{* * *}$ \\
\hline Frequency of defecation & $0.7 \pm 0.28$ & $0.6 \pm 0.29$ & $1.5 \pm 0.42$ \\
\hline Frequency of urination & $0.3 \pm 0.13$ & $0.4 \pm 0.14$ & $0.9 \pm 0.30$ \\
\hline Number of entries in the box & $7.5 \pm 0.93$ & $2.5 \pm 0.60^{* * * *}$ & $4.6 \pm 0.98^{*}$ \\
\hline Number of marking on the territory & $0.7 \pm 0.28$ & $0.4 \pm 0.15$ & $5.2 \pm 0.80^{* * *}$ \\
\hline Frequency of rearing & $10.4 \pm 1.23$ & $12.0 \pm 2.08$ & $18.2 \pm 2.14 *$ \\
\hline
\end{tabular}

Note: The comparisons between males and females of $M$. h. lydius and between males of the two investigated subspecies were made.

Abbreviations see in Tab. 3; for the urination and defecation $p>0.1$

lenishchev et al., 2003). The same option of insulation between $M$. g. guentheri and M. h. lydius (Golenishchev \& Malikov, 2011) was registered. In both combinations of crossbreeding, sterile hybrid males and fertile females were received.

The third variant of postzygotic isolation in the hybridization of $M$. paradoxus with $M$. socialis as a decline of fertility in F1 hybrid males was noted (Golenishchev et al., 2002) or a part of the males were sterile (Zorenko, 2012, 2013). Males in backcrossing in the first and second generations could be completely sterile. Backcrossing easily happened during encounters of hybrids with the parental form of $M$. socialis. A similar situation is observed with $M$. $h$. lydius and $M . h$. strandzensis. A partial sterility was maintained in the F1 till F4. The greatest manifestation of sterility like absence of sperm, lower sperm content and immobility of sperm occurred in the backcrosses. The findings suggest a good expression of genome incompatibility of the two subspecies (Borodin et al., 2006). For a significant divergence of the Asian and European subspecies of $M$. hartingi also indicates the fact that after cross breeding of closely related forms the hybrid offspring had been with high vitality, heterosis effect in the size and weight, greater rate of growth and the Infant mortality was generally lower (Schwartz et al., 1960; Zorenko, 2013).

The fourth variant of postzygotic isolation in subspecies forms of $M$. socialis was noted. Although they have fertile hybrids, the intensity of their reproduction decreased. It was a well marked effect of prolonged isolation and led to the accumulation of small differences in morphology, behavior and the development of the subspecies (Zorenko et al., 1997).

The possibilities of the taxonomy could be expanded, if for the taxonomic characteristics are used not only the morphological structures, but the animal behavior, too. Exploratory and mating behavior is presented by many patterns which were genetically (van Abeleen, 1970; Crusio et al., 1989) or by environmentally controlled (Frynta, 1994), so they were often used for the comparison of closely related taxa (Frynta, 1994; Vigorov et al., 1977; Vigorov, 1980; Zorenko et al., 1989). Exploratory behavior was evoked by novel stimuli and consists of behavioral acts and postures that permit the collection of information about new objects and unfamiliar parts of the environment (Crusio \& van Abeelen, 1986; Meshkova \& Fedorovich, 1996; Zorenko et al., 1989).

Using the open-field test showed a significant divergence of the two subspecies of $M$. hartingi on exploratory behavior pattern. Out of the 12 indicators of behavior in the open-field test nine were statistically significant (Tab. 6). The most significant change in the locomotor activity was observed and was correlated with the level of the Central nervous system (CNS) excitability (Krushinsky, 1991). M. h. lydius was characterized with a low level (value) of locomotor activity and low excitability of the CNS. 93\% of males showed a small number of crossed squares (60-150) and only in $7 \%$ of individuals a higher level of locomotion was reached (180-240 squares). The mobility was the highest in the first few minutes of the experiment, and than it sharply drops. An animal may cross only five to10 squares for a minute or sit still in the nest box or by the wall. Different situation in $M$. h. strandzensis was observed. Only $32 \%$ of the individuals were crossed relatively small number of squares (50-200), whereas 68\% of them the number of crossed squares exceeds 200 (694). In M. h. strandzensis almost the same level of the mobility was maintained throughout the whole experi- 

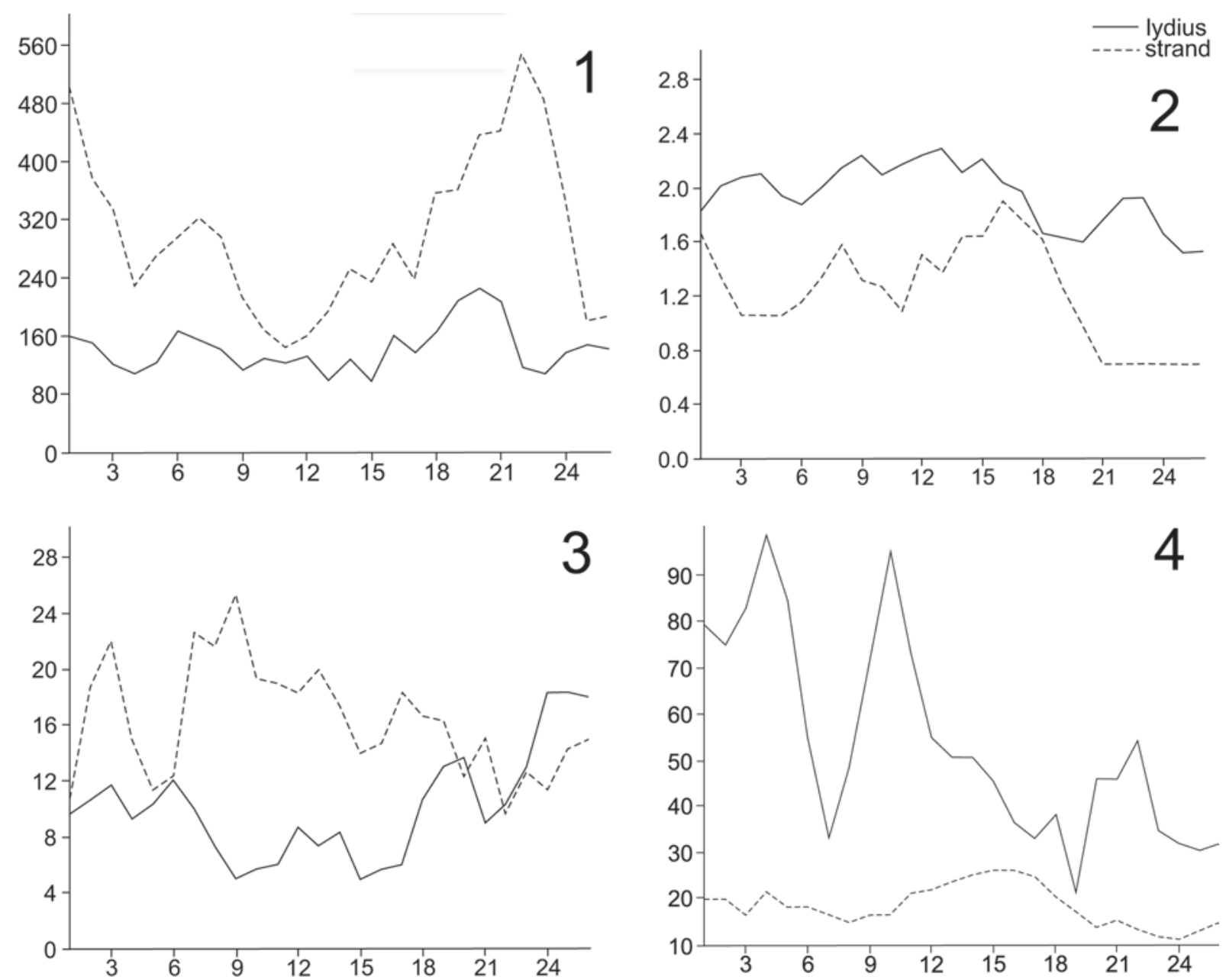

Fig. 4. Graphs of the exploratory behavior data of M. h. lydius (solid line) and M. h. strandzensis (dotted line): 1 - locomotor activity, 2 - immobility, 3 - vertical activity, 4 - autogrooming.

ment as in a minute a vole crosses average 25 to 30 squares. The novelty in the situation or in the environment decreases the proportion of individuals who have low value of locomotor activity.

A similar tendency was noted for the immobility, too. In voles of $M$. $h$. lydius more than $50 \%$ of males and $75 \%$ of females were frozen in place for 2-6 min. In M. h. strandzensis only $16 \%$ of males froze for 2 to 4 min., but in the majority of males the immobility was not characteristic. The subspecies differ in the level of exploratory behavior. Although the mobility of $M$. $h$. lydius was low, the voles pay more attention to the objects around (the nest box, the floor, walls of the "field"), they smell out, bite and scratch with paws. Autonomic manifestations of fear and emotion were the defecation and urination. The unknown situation was a significant stress factor for the voles and when they were under the stress, the influence of the autonomic nervous system was in particular on the intestinal peristalsis and bladder. This could be associated with an increase or suppression of the excretory functions of organism (Shepherd, 1983). Voles in a stressful situa- tion exude feces, but in the open-field test relative rarely defecation was indicated. The number of bowel movements and urination were weakly expressed and were in negative correlation with the locomotor activity, what was a typical not only for $M$. hartingi, but for most species of social voles.

The observed differences in the behavior of voles in the open-field test could be the result of the changes of the threshold of sensitivity to various environmental factors, as well as the threshold of the realization of motor acts that were emerged in the evolution of social voles.

Neophobia in $M$. h. strandzensis was weak, they were begun to occupy the central part of the field early, repeatedly reaching to the center and took the stand still position. On the contrary, in $M$. h. lydius all of these indicators were less pronounced and neophobia was good pronounced. It should be noted for the most of studied species like Alexandromys fortis (Büchner, 1889), Microtus ilaeus (Thomas, 1912), Lasiopodomys (Stenocranius) gregalis (Pallas, 1779), and L. brandtii (Radde, 1861) (Zorenko et al., 1989) and M. socialis 


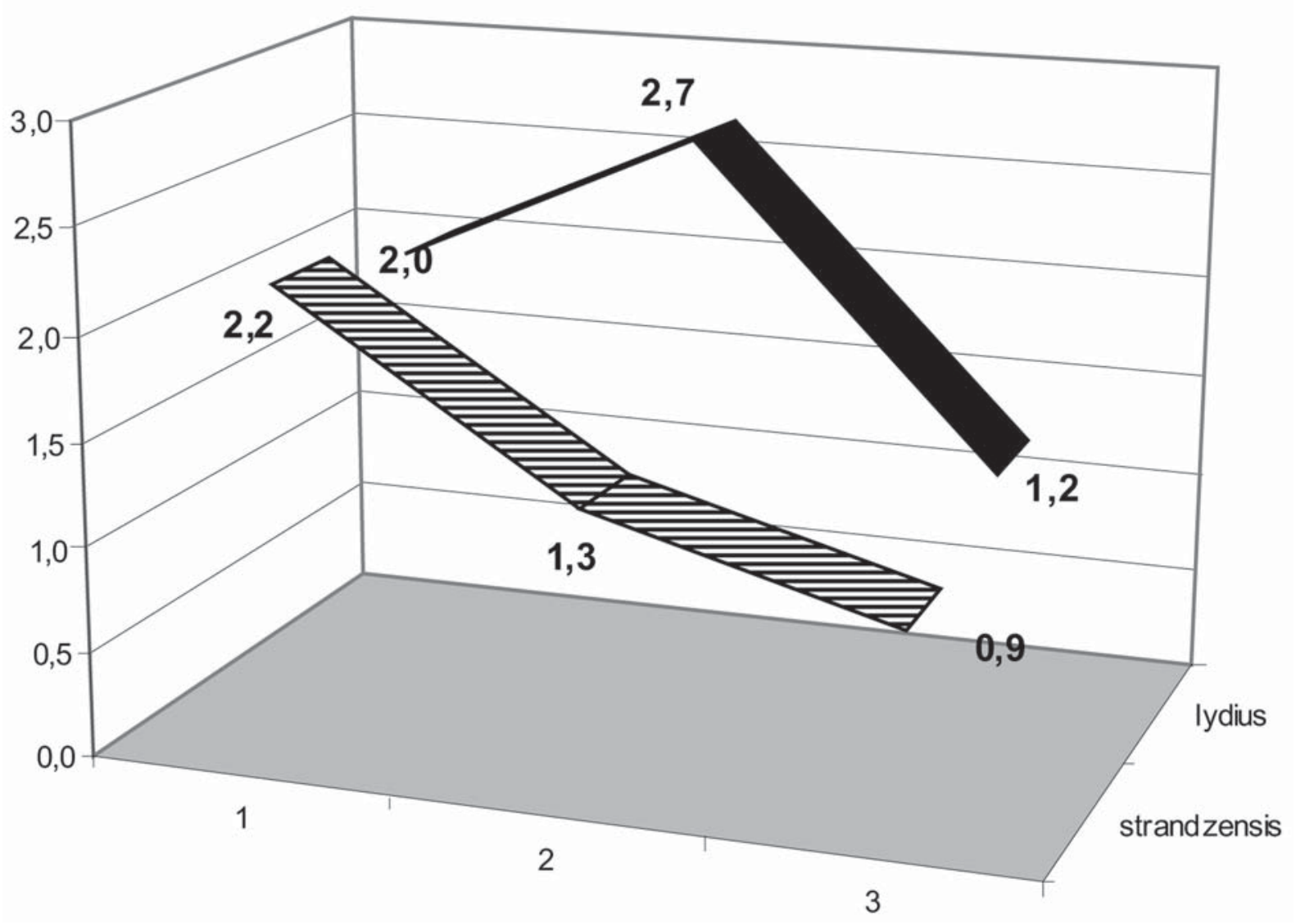

Fig. 5. Comparison between levels of locomotor exploring of the space (1), objective exploring of the space (2) and emotionality (3) of the males of M. hartingi subspecies using Shannon index.

goriensis Argyropulo, 1935 (Zorenko, 2013), the behavior of males and females were differing no more than two to three parameters. However, the females of $M$. h. lydius differ significantly in the majority of the parameters, such as mobility, immobility, the first intersection of the center and the exploration of the subjects. An increase on neophobia could be determined as the capacity for dispergation.

In general, should be noted Sumeriomys voles have a limited capacity for dispersion, usually their distribution area was considerably fragmented and as a result was formed a complex intraspecific structure with many subspecies (Gromov \& Erbaeva, 1995). Social voles were characterized with the formation of small family groups and even a tendency to monogamous relationships (Shchipanov \& Kasatkin, 1996; Shilova \& Kasatkin, 2000; Zorenko, 2013). Geographical barriers, as well as the fragmentation of the distribution area under the influence of climatic and biotopic factors had a greater impact on the species with reduced dispergation potential (Avise et al., 1987; Bond et al., 2001). The described trends in exploratory behavior of $M$. $h$. strandzensis could be the result of the voles' settlement on the Balkans. More mobile individuals of Asian voles (both males and females) could increase their disper- sion capacity and actively overcome the distance, thus have become founders of the European population. Therefore, in addition to the geographic isolation and gene drift, the populations of $M$. hartingi could be influenced by the selection. The directional selection could contribute to the formation of voles on the Balkans with high excitability of the CNS and could change the nature of exploratory behavior.

A significant divergence in the stereotype of the pairing of two subspecies of $M$. harting $i$ was observed also. From 11 selected for comparison patterns of sexual behavior in nine of them significant differences were marked. Differences in other parameters were marked too, but with no significant value. Have to note the subspecies of $M$. socialis was differed through less number (three to five) of significant differences (Zorenko, 2000). All species of the subgenus Sumeriomys were characterized by intromission model of mating, i.e. to achieve ejaculation male had to make several intromissions. The total number of intromission for the entire mating period for most of the species and subspecies of voles' group "socialis" was 15, and only in one subspecies of $M$. socialis binominatus Ellerman, 1941 was 24 . For $M$. h. strandzensis and $M$. h. lydius subspecies it was average 11.5 and 29.8 intromission respec- 
tively. Intromission model for mating for Microtus (46 intromissions during the whole copulatory period) and for the voles from genus Terricola (25) was established too (Zorenko, 2013). Individual variability of mating patterns was noticeable, so within a taxon there were always individuals with an increased or decreased expression of a particular pattern of behavior (CV range from 15 to $70 \%$ for different parameters of mating). Therefore, factors leading to changes in the parameters of the mating may occur in the same way as for the exploratory behavior (isolation, gene drift, selection).

Changes in the individual development and growth of young animals of both subspecies of $M$. hartingi during the first month of life were observed. Pups of $M$. $h$. strandzensis grow and develop more slowly than young of $M$. $h$. lydius. It was known that taxonomic differences may occur during this period, when the young are less dependent on external conditions (Bashenina, 1977). Perhaps some abnormalities in the morphogenetic program (so called timer of ontogeny) of $M$. $h$. strandzensis had also led to a slowdown of ontogeny. These changes could be adaptive in nature and could be related to the need the young to linger longer in the parent group. This indirectly indicates a manifestation of play activity. The level of activity in $M$. h. strandzensis was $1.5 \pm 0.29$ elements for the $10 \mathrm{~min}$ of the experiment (Zorenko \& Andersone, 1996). A play in lydius almost is absent. For comparison, for example, in $M$. schidlovskii play index was $5.8 \pm 2.70$. The increasing of the play activity correlates with the complexity of the family group structure (Zorenko \& Andersone 1996).

Differences in the structure of the karyotype between the two studied subspecies voles (Zima et al., 2013) and cytochrome $b$ gene mDNA (Kryštufek et al., 2009) were not found. However, voles from recently reported localities of the species in Eastern Rhodopes Mountains in Bulgaria (Atanasova et al., 2010; Minkova, 2004; our unpublished data) differ cytogenetically from the population in Strandzha Mountain regarding the morphology and distribution of heterochromatin in the autosomes and sex chromosomes (Chassovnikarova et al., 2008).

Changes in the parameters of the exploratory and sexual behavior, as well as in growth and development of young animals might also have epigenetic character. As was shown above, in the investigated group of $M . h$. lydius predominant were the voles with a phenotype for low locomotor activity and increased of the immobility caused by fear. Some animals, though, were with phenotype for prevail of locomotor activity and reduced immobility. In the European population of $M . h$. strandzensis an inverse relationship between the dominated behavior patterns was observed. Most of them have a high quantitative indicator of locomotor activity, which was a highest among all studied species and subspecies of the subgenus Sumeriomys (Zorenko, 2013).

The specifics of the behavior of the European $M . h$. strandzensis could be related to the expansion and dispersion of their ancestors in Europe. Epigenetic mod- ifications of specific genomic regions in response to variations in environmental conditions might to serve as a major source of variability in new different biological and behavioral phenotypes (Weaver, 2007). As Badyaev writes "the epigenetic interactions associated with maternal effects can capture and retain a novel adaptation for long evolutionary periods even before genetic determination of the new adaptation can evolve and with considerably lesser lethality than direct genetic effects" (Badyaev, 2008: 152-153).

The present areal of $M$. hartingi in Europe consists of several fragmented parts (Ondrias, 1965; 1966). The main factor, which defining and limiting the distribution of the voles and the fluctuation of their areal in past and present on the Balkans, was the climate and correlated steppe vegetation. Palynological analysis showed the last 30 thousand years in the northern Mediterranean region the xerophytic forests and sagebrush-grass steppe were prevailing (Simakova, 2008). Probably on some stage the vegetation was changed and a mosaic type was formed. It is known that rodents that live in conditions of Asian continental climate must be more resistant to adverse environmental conditions from the European species (Polyakov, 1959). For example, as occupant of a variety of climatic conditions of the region for the narrow-headed vole Lasoipodomys (Stenocranius) gregalis was easy to response to different adverse factors, while the social and especially the common vole $M$. arvalis was strongly suppressed by external conditions (as drought). These periods for settlement of $M$. hartingi were quite critical because of the stress increase as a response of the fragmented environment. Stress-induced epigenetic changes, which not affect the DNA sequence of nucleotides could be secured and transmitted to the next generation (Meaney \& Szyf, 2005).

Differences in the genome of the populations form the relevant differences which were manifested in the external and internal structure of the body as well as in behavior. From external signs such as fur color and morphometric differences in the structure of skull could be noted (Yi it \& Çolak, 2002), different rates of individual development (including the lack of play activity), special stereotype of mating and exploratory behavior and differences in the response to stress. Also slight differences in terms of size of sperm were noted (Zorenko \& Golenishchev, 2015) and epigenetic cranial polymorphism (Markov et al., 2014).

Active settlement of voles in Balkans could be happened in late Pleistocene during the regression of the Black Sea, which was occurred about 25 to 22 thousand years ago. In the glacial period the zone of the steppes was expanded and the distribution of voles was increased. About ten thousand years ago during the time of last Black Sea transgression the link between Black and Mediterranean seas was recovered through the Bosphorus and the Dardanelles (Velikanov et al., 1983; Esin et al., 2010; Yi it et al., 2012). The settlement of voles in the Balkans was ended and this period could be 
considered as the beginning of the isolation of the Asian and Balkan populations. A possibility was the insulation of the voles was happened later. In accordance with the hypothesis of Ryan \& Pitman (1999) the Bosphorus could be form 7500 to 5000 years ago when the Mediterranean Sea level have been risen as a result of the melting of glaciers and the waters of the Mediterranean Sea were flow into Black Sea. In any case, the isolation of the Balkans from Asia Minor could begin in the Holocene in the period of last phase of regression, when the level of the Mediterranean Sea has risen by nearly 100 meters (Karnaukhov \& Karnaukhov, 1997).

Nevertheless, this period on genetic isolation of populations was not long enough to recognize their status of independent species (Ferguson, 2002). Therefore, the question of the subspecies status of $M . h$. lydius remains open (Yi it \& Çolak, 2002). However, the European population of Harting' voles already reached considerable isolation for species or as defined of Pavlinov (1992) "speciesness". The violation of spermatogenesis, substantial changes in many forms of behavior and some morphological characteristics were an evidence for this.

It could be expected that the voles from the northwestern populations in Macedonia and Central Greece would have a much greater divergence, as they were relics from an early colonization of Europe during the Pleistocene. Voles from Strandzha Mountain may have an additional contact with the voles settled in the Holocene until the final interruption of communication between Europe and Asia. Perhaps, an evidence of hybridization and the existence of a hybrid zone in the Holocene was the specificity of weights of genitals of $M$. h. strandzensis. Compared with the other social voles the weight of testes and their epididymis in $M . h$. strandzensis were very small. In fertile hybrids F1 to F4 and backkroses it was remained close to that of $M$. $h$. strandzensis. This fact could not be explained by the specifics of the mating system and social organisation which is similar of the social vole species as whole. More likely that the decrease of the indices of the reproductive organs of males was due to the peculiarities of the European subspecies formation of $M . h$. strandzensis.

ACKNOWLEDGEMENTS. This work was partially supported by RFBR grants 13-04-00930-a and 1604-00983-a, and the Zoological Institute RAS (State Ithem No.01201351185). We would like to express our great gratitude to Professor Dr. Nuri Yi it from Zoology Division of the Department of Biology, Faculty of Sciences of Ankara University, Turkey for the help in the capture of Microtus hartingi lydius. We are grateful to the reviewers for the extensive comments and fruitful discussions of previous versions of the manuscript.

\section{References}

Akhverdyan M.R., Vorontsov N.N. \& Lyapunova E.A. 1991. [The shidlovsky's vole Microtus schidlovskii (Rodentia,
Cricetidae) - an independent species of fauna Armenia] // Biologichesky Zhurnal Armenii. Vol.4. No.44. P.266271 [in Russian].

Atanasova I., Raykov I., Raykova V. \& Vasilev V. 2010. Outlining the most northerly points of the habitat of Guenther"s vole Microtus guentheri (Danford \& Alston, 1888) in Bulgaria and some ecological notes // Annual of Konstsntin Preslavski University, Bulgaria, Faculty of Natural Sciences, Vol.20. No6. P.148-168.

Avise J.C., Arnold J., Ball R. et al. 1987. Intraspecific phylogeography: the mitochondrial DNA bridge between population genetics and systematics // Annual Review of Ecology, Evolution and Systematics. Vol.18. P.489-522.

Badyaev A.V. 2008. Maternal effects as generators of evolutionary change. A reassessment //Annals of the New York Academy of Sciences. No.1133. P.151-161.

Bashenina N.V. 1977. [The Trends in Adaptation of Small Rodents]. Moskva: Izdatel'stvo Nauka. 355 p. [in Russian].

Bond J.E., Hedin M.C., Ramirez M.G. \& Opell B.D. 2001. Deep molecular divergence in the absence of morphological and ecological change in the Californian coastal dune endemic trap-door spider Aptostichus simus // Molecular Ecology. Vol.10. No.4. P.899-910.

Borodin P.M., Barreiros-Gomez S.C., Zhelezova A.I., Bonvicino C.R. \& D'Andrea P.S. 2006. Reproductive isolation due to the genetic incompatibilities between Thrichomys pachyurus and two subspecies of Thrichomys apereoides (Rodentia, Echimyidae) // Genome. Vol.49. No.2. P.159-167.

Castiglia R. \& Capanna E. 2000. Contact zone between chromosomal races of Mus musculus domesticus. 2. Fertility and segregation in laboratory-reared and wild mice heterozygous for multiple robertsonian rearrangements // Heredity. Vol.85. P.147-156.

Chassovnikarova T.G., Markov G.G., Atanasov N.I. \& Dimitrov H.A. 2008. Sex chromosome polymorphism in Bulgarian populations of Microtus guentheri (Danford \& Alston, 1880) // Journal Natural History. Vol.42. No.58. P.261-267.

Crusio W.E., Schwegler H., van Abeelen J.H.F. 1989. Behavioral responses to novelty and structural variation of the hippocampus in mice. I. Quantitative-genetic analysis of behavior in the open-field. // Behavioral Brain Research. Vol.32. No1. P.75-80.

Crusio W.E. \& van Abeelen J.H.F. 1986. The genetic architecture of behavioral responses to novelty in mice // Heredity. Vol.56. P.55-63.

Dewsbury D.A. 1972. Patterns of copulatory behaviour in male mammals // The Quarterly Review of Biology. Vol.47. No.1. P.1-33.

Erman A. \& Parson P. 1984. [Genetics of Behavior and Evolution]. Translated from English. Moskva: Izdatel'stvo Mir. 566 p. [in Russian].

Esin N.V., Yanko-Hombach V. \& Kukleva O.N. 2010. Mathematical model of the Late Pleistocene and Holocene transgressions of the Black Sea // Quaternary International. Vol.225. P.180-190.

Ferguson J.W.H. 2002. On the use of genetic divergence for identifying species // Biological Journal of Linnaean Society. Vol.75. P.509-516. 
Frynta D. 1993 (1994). Exploratory behaviour in 12 Palaearctic mice species (Rodentia: Muridae): A comparative study using "free exploration" tests // Acta Societatis Zoologicae Bohemicae. Vol.57. P.173-182.

Golenishchev F.N. \& Abramson N.I. 2011. [New data on phylogeography of voles' subgenus Sumeriomys (Arvicolinae, Rodentia)] // Rozhnov V.V. et al. (eds.) Proceedings of International Conference "Mammals of Russia and Adjacent Territories". IX Congress of Theriological Society, RAS. Moscow: KMK Scientific Press. P.117 [in Russian].

Golenishchev F.N. \& Malikov V.G. 2011. [The systematics and distribution of the grey voles of the tribe Microtini (Rodentia, Arvicolinae) in the Caucasus and Asia Minor] // Movsesyan S.O. et al. (eds.) Proceeding of the International Conference "Biological diversity and conservation problems of the fauna of the Caucasus". 26-29 September 2011. Yerevan: LLC Spika. P.101-105 [in Russian].

Golenishchev F.N., Gerasimov C. \& Sablina O.V. 1991. [Reproduction, postnatal growth and development of the voles (subgenus Sumeriomys)] // Proceedings of Zoological Institute RAS. Vol.243. P.71-80 [in Russian with English summary].

Golenishchev F.N., Sablina O.V., Borodin P.M. \& Gerasimov S. 2002. Taxonomy of voles of the subgenus Sumeriomys Argyropulo, 1993 (Rodentia, Arvicolinae, Microtus) // Russian Journal of Theriology. Vol.1. No.1. P.43-55.

Golenishchev F.N., Malikov V.G., Nazari F., Vaziri A. Sh., Sablina O.V. \& Polyakov A.V. 2003. New species of vole of "guentheri" group (Rodentia, Arvicolinae, $\mathrm{Mi}$ crotus) from Iran // Russian Journal of Theriology. Vol.1. No.2. P.117-123.

Gromov I.M. \& Erbayeva M.A. 1995. [The Mammals of Russia and Adjacent Territories. Lagomorpha and Rodents]. Saint Perersburg: Zoologicheskii Institut RAN. 520 p. [in Russian].

Kurilo L.F. 2001. [Handbook WHO for laboratory study of human semen and sperm interaction with cervical mucous]. Moscow: MedPress. 144 p. [in Russian].

Karnaukhov A.V. \& Karnaukhov V.N. 1997. [Where the Siberian Rivers were flowing during the Ice Age?] // Priroda. No.1. P.46-55 [in Russian].

Krushinsky L.V. 1991. [Evolutionary-genetic Aspects of Behavior]. Moskva: Izdatel'stvo Nauka. 259 p. [in Russian].

Kryštufek B. \& Vohrálik V. 2005. Mammals of Turkey and Cyprus. Rodentia I: Sciuridae, Dipodidae, Gliridae, Arvicolinae. Ljubljana: Univerza na Primorskem, Znanstveno-raziskovalno središèe Koper, Založba Annales, Zgodovinsko društvo za južno Primorsko. 292 p.

Kryštufek B., Vohrálik V., Zareie R. \& Özkan B. 2009. Mithochondrial cytochrom $b$ sequences into the speciation of social voles in southwest Asia // Biological Journal of Linnaean Society. Vol.98. P.121-128.

Makaryan C.R., Dadikyan K.M. \& Papanyan C.B. 1991. [Morphological features of hybrids of voles (female Misrotus schidlovskii Argyropule $1933 \times$ male Microtus socialis binominatus Ellerm, 1941)] // Biologichesky Zhurnal Armenii. Vol.44, No.3-4. P.175-186 [in Russian].
Markov G. 1960. Microtus güentheri strandzensis subsp. nov., eine neue wühlmaus-unterart im Strandza-Gebirge, Ostbulgarien // Comptes Rendus de 1'Academia Bulgare des Sciences. Vol.13. P.615-617.

Markov G., Yi it N., Çolak E., Kocheva M. \& Gospodinova M. 2014. Epigenetic diversity and similarity of the voles of "guentheri" group (Mammalia: Rodentia) in Anatolian Peninsula and South-Eastern part of the Balkan Peninsula // Acta Zoologica Bulgarica. Vol. 66. No.2. P.159-164.

Meaney M.J. \& Szyf M. 2005. Environmental programming of stress responses through DNA methylation: life at the interface between a dynamic environment and a fixed genome // Dialogues Clinic Neuroscience. Vol.7. P.103123.

Meshkova N.N. \& Fedorovich E.F. 1996. [Exploratory Behavior, Imitation and Play as Psychological Mechanisms of Adaptation of Animals to the Urbanized Environment]. Moscow: Izdatel'stvo Argus. 224 p. [in Russian].

Minkova T. 2004. Small mammals (Insectivora and Rodentia) of the Eastern Rhodopes (Bulgaria) // Beron P., Popov A. (eds.). Biodiversity of Bulgaria. 2. Biodiversity of Eastern Rhodopes (Bulgaria and Greece). Sofia: Pensoft \& Nat. Mus. Hist. P.895-906.

Musser G.G. \& Carleton M.D. 2005. Superfamily Muroidea // Wilson D.E. \& Reeder A.M. (eds.). Mammal Species of the World. Third edition. Baltimore: Johns Hopkins University Press. Vol.2. P.894-1531.

Ondrias J.C. 1965. Contribution to the knowledge of Microtus guentheri hartingi from Thebes, Greece // Mammalia. Vol.29. P.489-506.

Ondrias J.C. 1966. The taxonomy and geographical distribution of the rodents of Greece // Säugetierkundliche Mittelungen. Vol.14. P.1-136.

Pavlinov I.Ya. 1992. [Whether there is a biological species or what is the harm of the systematics] // Zhurnal Obschei Biologii. Vol.53. No.5. P.757-767 [in Russian].

Perissoratis C. \& Conispoliatis N. 2003. The impacts of sealevel changes during latest Pleistocene and Holocene times on the morphology of the Ionian and Aegean seas (SE Alpine Europe) // Marine Geology. Vol.164. No.34. P.145-156.

Polyakov I.Y. 1959. [Morphophysiological variability of populations of rodents under the influence of environmental conditions] // Soveshchanie po Ekologicheskoi Fiziologii. Part 1. Moskva-Leningrad: AN SSSR Publ. P.46-49 [in Russian].

Ryan W.B. \& Pitman W.C. 1999. Noah's Flood: The New Scientific Discoveries about the Event That Changed History. New York: Simon and Schuster. 319 p.

Schwartz S.S., Kopein K.I. \& Pokrovsky A.V. 1960. [Comparative study of some biological features of voles $\mathrm{Mi}$ crotus gregalis gregalis Pall. and Microtus gregalis major Ogn. and their hybrids] // Zoologicheskii Zhurnal. Vol.39. No.6. P.912-926 [in Russian].

Shchipanov N.A. \& Kasatkin M.V. 1996. [Microtus socialis in changes landscapes of south Dagestan: population aspect of survival] // Zoologicheskii Zhurnal. Vol.75. No.9. P.1412-1426 [in Russian with English summary]. Shepherd G. 1983. Neurobiology. New York, Oxford: Oxford University Press. 500 p. 
Shilova S.A. \& Kasatkin M.V. 2000. [A comparative analysis of the population structure of social vole (Microtus socialis Pall., 1773, Cricetidae, Rodentia) in different parts of the area] // Ekologiya. No.4. P.287-294 [in Russian with English summary].

Simakova A.N. 2008. Development of a vegetable cover of East European Plain and Western Europe in the late Neopleistocene - the middle Holocene (33-4.8 BP). Avtoreferat na soiskanie uchenoi stepeni kandidata geologicheskih i mineralogicheskih nauk. Moskva. 34 p. [in Russian].

Thanou E., Fraguedakis-Tsolis S.E., Chondropoulos B., Paragamian K. \& Lymberakis P. 2011. Ancient DNA clarifies the systematic and phylogenetic status of the only vole species living in Africa // Borsch T., Giere P., Hoffmann J. et al. (eds.) BioSystematics Berlin. Berlin: Freie Universität Berlin. P.355-356.

Thanou E., Tryfonopoulos G., Chondropoulos B. \& Fraguedakis-Tsolis S.E. 2012. Comparative phylogeography of the live Greek vole species infers the existence of multiple South Balkan subrefugia // Italian Journal of Zoology. Vol.79. No.3. P.363-376.

van Abeleen J.H.F. 1970. Genetics of rearing behavior in mice // Behavioural Genetics. Vol.1. P.71-76.

Velikanov A., Danov Ch., Marikov Ch. \& Vladeev P. 1983. [Black sea]. Leningrad: Hidrometeoizdat. 408 p. [in Russian].

Vigorov J.L., Bolshakov V.N. \& Pokrovsky A.V. 1977. [Experimental study of the exploratory and emotional behavior of four species of voles] // Povedenie Mlekopitayushchikh. Moskva: Izdatel'stvo Nauka. P.247-267 [in Russian].

Vigorov J.L. 1980. [Specific and ecological differences of an exploratory behavior of some small rodents' species] // Ryabitsev V.K. (ed.) Ekologicheskie Aspekty Povedeniya Zhivotnikh. Sverdlovsk: Izdatel'stvo Uralskogo Nauchnogo Tsentra AN SSSR. P.61-81 [in Russian].

Weaver I.C. 2007. Epigenetic programming by maternal behavior and pharmacological intervention. Nature versus nurture: let's call the whole thing off // Epigenetics. Vol.2. No.1. P.22-28.

Yi it N. \& Çolak E. 2002. On the distribution and taxonomic status of Mirotus guentheri Danford and Alston, 1880 and Microtus lydius Blackler, 1916 (Mammalia: Rodentia) in Turkey // Turkish Journal of Zoology. Vol.26. P.197-204.

Yi it N., Markov G., Çolak E.., Kocheva M., Sayg 1 F., Yüce D. \& Çam P. 2012. Phenotypic Features of the "Guentheri" Group Vole (Mammalia: Rodentia) in Turkey and Southeast Bulgaria: Evidence for Its Taxonomic Detachment // Acta Zoologica Bulgarica. Vol.64. No.1. P. $23-32$
Zakharyan C.A. 1958. [Systematics of Microtus guentheri schidlovskii Arg.] // Doklady AN Armyanskoy SSR. Vol.26. No.2. P.125-128 [in Russian].

Zhabin C.G, Artifeksov S.B., Nagaytsev V.M., Artifeksova M.S., Treshchenkov E.A. \& Pavlenko I.I. 2010. [Modern ideas of maturation of spermatozoa in the epididymis of testis] // Problemi reproduktsii. Vol.2. P.66-73 [in Russian with English summary].

Zima J., Arslan A., Benda P., Macholàn M. \& Kryštufek B. 2013. Chromosomal variation in social voles: a Robertsonian fusion in Gûnter's vole // Acta Theriologica. Vol.58. P.255-265.

Zorenko T.A. 1996. [Reproductive behavior of mammals] // Laboratornye Zhivotnye. Vol.6. No.2. P.95-109 [in Russian with English summary].

Zorenko T.A. 2000. [Morphology of genitals and sexual behavior of social voles of the subgenus Sumeriomys (Arvicolinae, Microtus)] // Zoologicheskii Zhurnal. Vol.79 No.8. P.990-999 [in Russian with English summary].

Zorenko T.A. 2012. [The taxonomical status of the social vole from Kopet Dagh] // Litvinov Yu.N. et al. (eds.). Aktual'nye Problemy Sovremennoi Teriologii. Novosibirsk: LLC Subregion Info. P.51 [in Russian].

Zorenko T. 2013. [Social Voles of the Subgenus Sumeriomys: Systematics, Biology and Behaviour]. Saarbrücken: Palmariun Academic Publishing. 541 p. [in Russian].

Zorenko T.A. \& Andersone Zh.E. 1996. [Play behaviour in voles (Rodentia, Arvicolinae)] // Zoologicheskii Zhurnal. Vol.75. No.10. P.1560-1572 [in Russian with English summary].

Zorenko T. \& Golenishchev F. 2015. The spermatozoa structure peculiarities of the subgenus Sumeriomys Argyropulo, 1933 (Rodentia, Arvicolinae, Microtus) // Russian Journal of Theriology. Vol.14. No.1. P.105-111.

Zorenko T.A. \& Malygin V.M. 1984. [The effect of the mechanisms of ethological reproductive isolation for the hybridization of three species of common voles group arvalis (Microtus, Cricetidae)] // Zoologicheskii Zhurnal. Vol.63. No.7. P.1072-1983 [in Russian with English summary].

Zorenko T.A., Zakharov K.V. \& Berezina R.J. 1989. [Exploratory behavior of voles: microevolutional and taxonomical aspects] // Zorenko T.A. \& Zakharov K.V. (eds.) Aktualnye Problemy Zoologii. Riga: University of Latvia. P.57-110 [in Russian with English summary].

Zorenko T.A., Golenishchev F.N. \& Skinderskaya I.A. 1997. [Peculiarities of the behaviour in social voles of the subgenus Sumeriomys (Arvicolinae, Microtus) in hybridization] // Baltic Journal of Laboratory Animal Science. Vol.7. No.2. P.77-102 [in Russian with English summary]. 